\title{
The flow field of the upper hypoxic eastern tropical North Atlantic oxygen minimum zone
}

\author{
L. Stramma ${ }^{1}$, R. Czeschel ${ }^{1}$, T. Tanhua ${ }^{1}$, P. Brandt ${ }^{1,2}$, M. Visbeck ${ }^{1,2}$, and B. S. Giese ${ }^{3}$ \\ ${ }^{1}$ GEOMAR Helmholtz Centre for Ocean Research Kiel, Düsternbrooker Weg 20, 24105 Kiel, Germany \\ ${ }^{2}$ Kiel University, Christian-Albrechts-Platz 4, 24118 Kiel, Germany \\ ${ }^{3}$ Department of Oceanography, Texas A\&M University, College Station, Texas, USA
}

Correspondence to: L. Stramma (lstramma@geomar.de)

Received: 13 August 2015 - Published in Ocean Sci. Discuss.: 15 September 2015

Revised: 2 December 2015 - Accepted: 23 December 2015 - Published: 18 January 2016

\begin{abstract}
A subsurface low oxygen zone is located in the eastern tropical North Atlantic Ocean (ETNA) in the upper ocean with the core of the hypoxic $\left(\mathrm{O}_{2} \leqq 60 \mu \mathrm{mol} \mathrm{kg}{ }^{-1}\right)$ oxygen minimum zone (OMZ) at 400 to $500 \mathrm{~m}$ depth. The subsurface circulation in the $\mathrm{OMZ}$ region is derived from observations and data assimilation results. Measurements in the ETNA of velocity, oxygen and of a tracer $\left(\mathrm{CF}_{3} \mathrm{SF}_{5}\right)$ that was released in April 2008 at $\sim 8^{\circ} \mathrm{N}, 23^{\circ} \mathrm{W}$ (at $\sim 330 \mathrm{~m}$ depth) in November-December 2008, in November-December 2009 and October-November 2010 show the circulation in the upper part of the OMZ with spreading to the east in the North Equatorial Countercurrent (NECC) region and northwestward around the Guinea Dome. Three floats equipped with oxygen sensors deployed at $\sim 8^{\circ} \mathrm{N}, 23^{\circ} \mathrm{W}$ with parking depths at 330, 350 and $400 \mathrm{~m}$ depths were used to estimate velocity along the float trajectory at the surface and at the parking depth. At the $350 \mathrm{~m}$ park depth north of $9^{\circ} \mathrm{N}$ a cyclonic northwestward flow across the OMZ was observed. The northward drift of a float into the upper OMZ and a stronger cyclonic flow around the Guinea Dome seem to be connected to a strong Atlantic Meridional Mode (AMM) event in 2009. A near-surface cyclonic circulation cell east of the Cape Verde Islands reaches down into the OMZ layer. The circulation of the upper OMZ mirrors the near-surface circulation. Oxygen measurements from the cruises used here, as well as from other recent cruises up to the year 2014, confirm the continuous deoxygenation trend in the upper OMZ since the 1960s near the Guinea Dome. The three floats deployed with the tracer show spreading paths consistent with the overall observed tracer spreading. Oxygen sensors on the floats remained well calibrated for more than 20
\end{abstract}

months, and so the oxygen profiles can be used to investigate mesoscale eddy signatures. Mesoscale eddies may modify the oxygen distribution in OMZs. However, in general eddies are less energetic in the ETNA south of the Cape Verde Islands compared to similar latitudes in the eastern tropical South Pacific.

\section{Introduction}

In the eastern tropical North Atlantic (ETNA) a subsurface low-oxygen zone exists with a pronounced minimum in oxygen at about 400 to $500 \mathrm{~m}$ depth. South and east of the Cape Verde Islands the oxygen minimum is strongest and is referred to as an oxygen minimum zone (OMZ). This $\mathrm{OMZ}$ is hypoxic (oxygen concentrations drop below $\sim 60$ to $120 \mu \mathrm{mol} \mathrm{kg}{ }^{-1}$; e.g., Stramma et al., 2008a), while OMZs in the eastern tropical South Pacific and northern Indian Ocean are suboxic (oxygen concentrations below about 4.5$10.0 \mu \mathrm{mol} \mathrm{kg}{ }^{-1}$; e.g., Karstensen et al., 2008; Stramma et al., 2008a). Under hypoxic conditions key mobile macroorganisms, such as tuna and marlin, are stressed (Stramma et al., 2012), while in suboxic regions dramatically different ecosystems exist, and under extreme circumstances nitrate becomes involved in respiration (e.g., Kalvelage et al., 2013). A vertical expansion of the OMZ and a decrease in OMZ core oxygen concentrations are detected in the tropical Atlantic and Pacific oceans (Stramma et al., 2008a). Since the year 2009, record-low dissolved oxygen values with less than $40 \mu \mathrm{mol} \mathrm{kg} \mathrm{kg}^{-1}$ were observed in the core of the ETNA 
OMZ (Stramma et al., 2009). If such a trend continues, the ETNA region might become suboxic in the future.

The structure of the OMZ is a consequence of the balance between the supply of oxygen through ventilation and circulation, oxygen production by photosynthesis and oxygen consumption by remineralization of sinking organic matter. Brandt et al. (2015) summarize the oxygen supply by energetic equatorial current bands as well as the present knowledge on vertical and lateral mixing, advection and consumption within the OMZ. Oxygen variability might be related to changes in the strength of latitudinally stacked zonal jets as derived by Brandt et al. (2010) that result in changes in the advective pathways to the ETNA OMZ, with likely the strongest impact in the upper 300-400 $\mathrm{m}$ of the water column (Hahn et al., 2014). The importance of the equatorial current system for the mean oxygen distribution is also revealed by high-resolution model simulations showing the oxygen supply at the Equator from a case with a more realistic representation of the circulation, as compared with coarser-resolution models (Duteil et al., 2014).

In terms of water masses, the core of the North Atlantic OMZ is comprised of Atlantic Central Water and Antarctic Intermediate Water (AAIW) layers. The Central Water is bounded by the isopycnals $\sigma_{\theta}=25.8$ and $27.1 \mathrm{~kg} \mathrm{~m}^{-3}$ (Stramma et al., 2008b). Two types of Central Water are found in the eastern tropical Atlantic Ocean. North of the Cape Verde Islands, North Atlantic Central Water (NACW) is found, while south of the Cape Verde Islands, South Atlantic Central Water (SACW) dominates. There is an inclined boundary between NACW and SACW rising from south to north, i.e., SACW lying on top of NACW (Tomczak, 1984); hence, near the Cape Verde Islands the lower OMZ is more influenced by NACW than in the upper OMZ layers. Based on this Central Water distribution, Peña-Izquierdo et al. (2015) proposed different flow regimes for the upper and intermediate Central Water layer separated by the isopycnal $\sigma_{\theta}=26.8 \mathrm{~kg} \mathrm{~m}^{-3}$ at about $300 \mathrm{~m}$ depth. The AAIW signature is most prominent below the OMZ core and spreads northward near the African continent, reaching as far north as $32.5^{\circ} \mathrm{N}$ (Machin and Pelegrí, 2009).

To better understand the existence of the OMZ, the oxygen supply paths and the oxygen changes, it is necessary to know the flow field in this region. Some flow field schematics exist for the upper ocean circulation; however, knowledge of the circulation in the depth range of the OMZ is very limited. The major supply paths of oxygen above and in the uppermost reaches of the OMZ in the eastern tropical North Atlantic are from the eastward flowing and latitudinally stacked zonal jets at and near the Equator (Brandt et al., 2015) and from the North Equatorial Countercurrent (NECC). Sometimes the NECC is obscured by the westward Ekman flow component at the surface. Two current bands of the NECC were briefly mentioned by Richardson and Reverdin (1987) and "rediscovered" in observations (Stramma et al., 2005) and modelling efforts (Urbano et al., 2006), the northern branch named the nNECC. The two NECC branches (Fig. 1) exist between $\sim 3$ and $\sim 10^{\circ} \mathrm{N}$. The NECC originates in the North Brazil Current Retroflection (e.g., Schott et al., 1998) and carries water from the South Atlantic. Below the Ekman layer recirculation from the Northern Hemisphere subtropical gyre contributes to the flow within the NECC (Lumpkin and Garzoli, 2005). The property distribution within the ETNA OMZ shows the lowest oxygen concentrations north of the NECC at about 400 to $500 \mathrm{~m}$ depth just above the boundary between Central Water and Antarctic Intermediate Water. The NECC is seasonally connected to the North Equatorial Undercurrent (NEUC) at 4 to $6^{\circ} \mathrm{N}$ and together with its northern branch at 8 to $10^{\circ} \mathrm{N}$ supplies oxygen-rich water to the OMZ, most pronounced in summer and fall (Stramma et al., 2008b). The NECC velocities are strongest in summer and fall, but a weak eastward NECC also exists in winter and spring with lower oxygen content compared to summer and fall (Stramma et al., 2008b). Radon transform analysis (Deans, 1983) indicates that the zonal propagation characteristics of the NECC are consistent with long Rossby waves (Hormann et al., 2012). Along-shore wind fluctuations and equatorially forced coastal Kelvin waves are found to be responsible for the excitation of annual- and semiannualpropagating Rossby waves in the eastern sub-basin (Chu et al., 2007). The NECC splits in the eastern basin (e.g., Stramma and Schott, 1999), with one current band continuing eastward into the Guinea Basin, while the other one turns northward and flows off the African coast and is called the Mauritania Current (MC; e.g., Peña-Izquierdo et al., 2012) off Mauritania. South of the NECC, a northern band of the South Equatorial Current (nSEC) flows westward north of the Equator, while the North Equatorial Current (NEC) limits the OMZ region to the north of the Cape Verde Islands (Fig. 1). Between the Cape Verde Islands and the African shelf, a permanent cyclonic feature exists year-round (Mittelstaedt, 1983).

Ventilation of the OMZ at 300 to $600 \mathrm{~m}$ depth is weaker compared to the strong oxygen supply at 150 to $300 \mathrm{~m}$ depth (e.g., Fischer et al., 2013; Hahn et al., 2014). South of the Cape Verde Islands there is a large-scale cyclonic circulation feature with an upward displacement of isotherms at a depth of more than $300 \mathrm{~m}$ called the Guinea Dome (Siedler et al., 1992). The Guinea Dome (GD) exists all year-round, although it is weaker in winter. The upper thermocline center of the dome is found at $9^{\circ} \mathrm{N}, 25^{\circ} \mathrm{W}$ in summer and at $10.5^{\circ} \mathrm{N}, 22^{\circ} \mathrm{W}$ in winter (Siedler et al., 1992). Westward drainage of oxygen-poor water takes place north of the Guinea Dome center, i.e., north of $10^{\circ} \mathrm{N}$, and is most pronounced at a depth of 400 to $600 \mathrm{~m}$ (Stramma et al., 2008b). The flow field at $400 \mathrm{~m}$ depth (Stramma et al., 2008b; their Fig. 12b) is similar to the flow field described for the upper ocean, including the cyclonic feature described for the region between the Cape Verde Islands and Africa.

Mesoscale eddies are the main source of lateral oxygen supply to OMZs. Hahn et al. (2014) found that the eddy- 


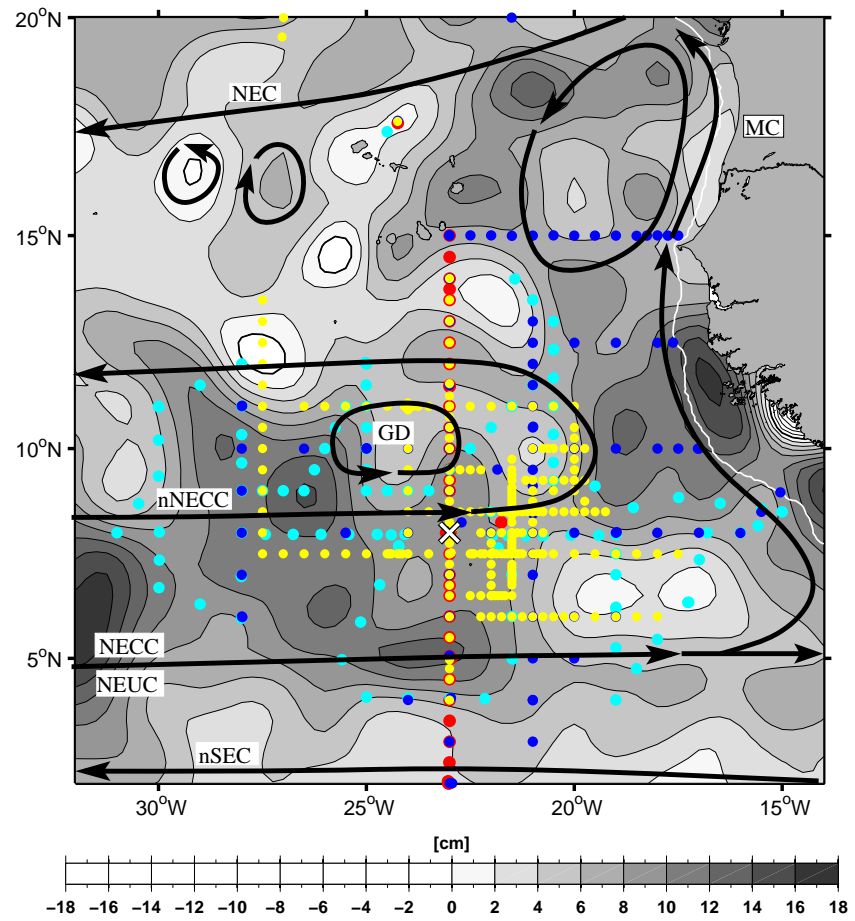

Figure 1. Aviso sea level height anomaly (in $\mathrm{cm}$ ) for 25 November 2009; cyclonic features are shown in bright color, anticyclonic ones in dark grey. The CTD stations of R/V Merian cruise MSM10/1 in November-December 2008 (yellow dots), of R/V Meteor cruise M80/1 in November 2009 (red dots), of cruise M80/2 in December 2009 (cyan dots) and of R/V Meteor cruise M83/1 in October-November 2010 (blue dots) are included. The white line off Africa marks the $200 \mathrm{~m}$ depth contour. The white cross with a black frame at $\sim 8^{\circ} \mathrm{N}, 23^{\circ} \mathrm{W}$ marks the location of the tracer release. Some upper ocean current bands based on earlier schematics (e.g., Mittelstaedt, 1983; Stramma and Schott, 1999; Stramma et al., 2008b; Peña-Izquierdo et al., 2012; Brandt et al., 2015) are shown as solid black lines. For current names please refer to the text. Cyclonic as well as anticyclonic eddies are indicated in a location with corresponding sea level height anomaly.

driven meridional oxygen supply is the dominant term in the oxygen balance at the core depth of the OMZ. Moreover, energetic eddies, generated near the eastern boundary, carry oxygen anomalies westward, eventually dissipate and may modify the oxygen distribution in the OMZs. In the ETNA region such eddies are observed mainly on the poleward side of the OMZs (Chelton et al., 2011). In the eastern tropical South Pacific (ETSP) eddies are strong, particularly affecting the flow and property fields of the upper several hundred meters of the ocean (e.g., Stramma et al., 2013; Czeschel et al., 2015). Three types of eddies have been identified in both regions: cyclonic, anticyclonic and mode water eddies (e.g., McGillicuddy Jr. et al., 2007). Cyclonic eddies have an uplift of isopycnals, anticyclonic eddies a downward shift of isopycnals, while mode water eddies derive their name from a thick lens of water that deepens the main pycnocline while shoaling the seasonal pycnocline. Mode water eddies show an uplift of the isopycnals near the surface and a downward shift of isopycnals below the surface layer, and the direction of rotation is the same as of anticyclonic eddies.

To investigate time-integrated diapycnal fluxes in the upper boundary of the ETNA OMZ, a tracer release experiment (GUTRE, Guinea Upwelling Tracer Release Experiment) was performed by releasing $92 \mathrm{~kg}$ of $\mathrm{CF}_{3} \mathrm{SF}_{5}$ (Ho et al., 2008) between 24 and 28 April 2008 at $\sim 8^{\circ} \mathrm{N}, 23^{\circ} \mathrm{W}$ on the density surface $\sigma_{\theta}=26.88 \mathrm{~kg} \mathrm{~m}^{-3}$ at a depth of about $330 \mathrm{~m}$ (Banyte et al., 2012). Three profiling floats with oxygen sensors were deployed during the tracer release. Subsequently three main cruises were carried out 7,20 and 30 months after the tracer release to investigate the spreading of the tracer (Banyte et al., 2012, 2013).

We use the three floats deployed at the tracer release site and hydrographic measurements from a cruise 7 months after the tracer release, two cruise legs 20 months after the tracer release in November and December 2009 and one cruise leg about 30 months after the tracer release to investigate the flow field of the OMZ and eddy signatures in the ETNA. We compare the float trajectories with the large-scale circulation and the spreading of the tracer, compare the observations with a data assimilation model and use recent measurements to extend an oxygen change time series. While previous studies focused on the $23^{\circ} \mathrm{W}$ section or on hydrographic and current meter measurements from single cruises, here we combine different measurements particularly including float and tracer measurements to investigate the flow field and oxygen distribution of the OMZ in the ETNA varying on intraseasonal and seasonal timescales.

\section{Data sets}

\subsection{Shipboard measurements}

Cruises M80/1 and M80/2 (Fig. 1) on the German R/V Meteor took place in November and December 2009 to investigate factors that control the intensity and areal extent of the OMZ in the eastern tropical North Atlantic Ocean. The first leg (M80/1; 26 October to 23 November 2009; MindeloMindelo (Cape Verde Islands); referred to as November 2009 in the following) reoccupied a section along $23^{\circ} \mathrm{W}$ that had been measured before and afterwards several times, while the second leg (M80/2; 26 November to 22 December 2009; Mindelo-Dakar, referred to as December 2009 in the following) was focussed on the GUTRE spatial survey of the OMZ with tracer measurements from samples from a conventional CTD rosette.

Two shipboard ADCP systems were used to record ocean velocity in November-December 2009: an RDI OceanSurveyor $75 \mathrm{kHz}$ ADCP provided the velocity distribution to about $600 \mathrm{~m}$ depth, while a $38 \mathrm{kHz}$ ADCP provided velocity profiles down to about $1000 \mathrm{~m}$ depth. In November 2009 
a $75 \mathrm{kHz}$ ADCP was used on the $23^{\circ} \mathrm{W}$ section on the southward section and a $38 \mathrm{kHz}$ ADCP was used on the northward return leg. On M80/2 in December 2009 only the $75 \mathrm{kHz}$ ADCP was used for current measurements.

A Seabird CTD system with a GO rosette with $2410 \mathrm{~L}$ water bottles was used for water profiling and discrete water sampling on both cruises. The CTD system was used with double sensors for temperature, conductivity (salinity) and oxygen. The CTD oxygen sensors were calibrated with oxygen measurements obtained from discrete samples from the rosette applying the classical Winkler titration method, using a non-electronic titration stand (Winkler, 1888; Hansen, 1999). The precision of the oxygen titration determined during cruise M80/1 in November 2009 was $\pm 0.34 \mu \mathrm{mol} \mathrm{kg}{ }^{-1}$. The uncertainty of the CTD oxygen sensor calibration was determined with an rms of \pm 1.28 in November 2009 and $\pm 0.93 \mu \mathrm{mol} \mathrm{kg}^{-1}$ in December 2009 .

While the two cruise legs in late 2009 are used to describe the general hydrographic and velocity distribution in the OMZ region, two other tracer survey cruises (Fig. 1) are included to investigate changes in the tracer distribution. A research cruise on the R/V Merian (MSM10/1) was conducted 7 months after the tracer deployment leaving Ponta Delgada (Azores) on 31 October 2008, with similar equipment as on the cruise in December 2009. After a survey around the region of the tracer deployment location, the cruise ended in Mindelo on 6 December 2008.

An R/V Meteor cruise (M83/1) was carried out between 14 October 2010 (Las Palmas, Spain) and 13 November 2010 (Mindelo, Cape Verde Islands), again with similar equipment as on the cruise in December 2009. Due to some technical problems, no ADCP data are available for a short period at the southwestern sections of the cruise track. Four zonal sections were made toward the African continent at about 15 , $12.5,10$ and $8^{\circ} \mathrm{N}$, and the ADCP sections are used to investigate the meridional current field. Furthermore, the ADCP and tracer measurements are used for a comparison with the distribution in December 2009.

In addition to oxygen measurements along $23^{\circ} \mathrm{W}$ on MSM10/1 in November-December 2008, M80/1 in November 2009 and M83/1 in October-November 2010, several other recent cruises are used to extend the historical oxygen time series. The cruises used to extend the time series from 1960 to 2007 (Stramma et al., 2008a) to the year 2014 in the region $10-14^{\circ} \mathrm{N}, 20-30^{\circ} \mathrm{W}$ are a L'Atalante cruise (GEOMAR-4) in March 2008, a Merian cruise (MSM18/3) in June 2011, a Meteor cruise (M97) in June 2013 and a Meteor cruise (M106) in April 2014.

\subsection{Satellite and float data}

Aviso satellite derived altimeter sea surface height anomaly (SSHA) data were used to define the general background distribution of the surface circulation and to identify possible eddy signatures. The SSHA data used in this study are delayed time products and combine available data from all satellites. The data are resampled on a regular $0.25^{\circ} \times 0.25^{\circ}$ grid and are calculated with respect to a 7-year mean (http: //www.aviso.oceanobs.com).

The oxygen climatological fields are taken from the CSIRO Atlas of Regional Seas (CARS) 2009 digital climatology (Ridgway et al., 2002) with a $0.5^{\circ}$ geographical resolution.

Three profiling Argo floats with Aanderaa oxygen optode sensors were deployed on 24 and 26 April 2008 at about $\sim 8^{\circ} \mathrm{N}, 23^{\circ} \mathrm{W}$ at the tracer release site with parking depths at 330,350 and $400 \mathrm{~m}$ depth, named here $\mathrm{f} 330, \mathrm{f} 350$ and $\mathrm{f} 400$ (Table 1). The cycling interval is 10 days for the floats at 330 and $350 \mathrm{~m}$ depth and 7 days for the float at $400 \mathrm{~m}$ depth. The floats at 350 and $400 \mathrm{~m}$ depth were deployed at the same location and at the same time; however, the first data recording started 1 to 46 days after deployment (Table 1). The lifetime of the floats was 1.6, 3.7 and 4 years. The floats drifting at 330 to $400 \mathrm{~m}$ were targeted to analyze the tracer spreading behavior near the core of the OMZ of the eastern North Atlantic Ocean. The shallow parking depth of our floats is different compared to most floats of the Argo project, which have a parking depth typically between 1000 and $1500 \mathrm{~m}$ depth and can be used to describe the flow field in the deep depths layers (e.g., Cravatte et al., 2012). In December 2009 CTD profiles were taken in the area of the three floats, and a comparison of oxygen profiles shows good agreement in the surface layer and below the OMZ, while in the OMZ some differences exist, most likely due to time-space differences. The 100 to $800 \mathrm{~m}$ mean oxygen difference at $1 \mathrm{~m}$ steps between float $\mathrm{f3} 30$ and a CTD-oxygen profile 3 days and $68 \mathrm{~km}$ apart result in a difference of $-1.1 \mu \mathrm{mol} \mathrm{kg}{ }^{-1}$ (a negative value for higher CTD oxygen), for float $\mathrm{f} 3500$ days and $36 \mathrm{~km}$ apart of $-0.2 \mu \mathrm{mol} \mathrm{kg}{ }^{-1}$ (Fig. S1 in the Supplement), while for float $\mathrm{f} 400$ oxygen profiles are missing for the period of the ship cruise. In summary, the float oxygen measurements seem to be accurate after $\sim 20$ months operating time and possibly throughout the lifetime of the floats.

\subsection{The SODA assimilation model}

SODA (Simple Ocean Data Assimilation) combines Los Alamos's POP (Parallel Ocean Program) model with a sequential estimation data assimilation method (Carton et al., 2000; Carton and Giese, 2008). The SODA version used for this paper (SODA 2.2.4) is similar to earlier versions but with some important differences as described by Giese and Ray (2011). For the remainder of the paper, we use SODA to refer to the SODA 2.2.4 product mapped onto a uniform $0.5^{\circ} \times 0.5^{\circ} \times 40$ level grid $(22$ vertical levels in the upper $800 \mathrm{~m}$ depth). Version 2.2.4 is forced by the 20CRv2 (20th Century Reanalysis version 2) (Compo et al., 2011) wind stresses from 1871 to 2011 and uses atmospheric variables from $20 \mathrm{CRv} 2$ for the calculation of surface heat and freshwater fluxes using bulk formulae. As in earlier versions, SODA 
Table 1. Argo floats with oxygen sensors used here. The APEX floats had cycle intervals of 10 days, the PROVOR float of 7 days. The APEX floats stayed at the surface for about $13 \mathrm{~h}$, while the PROVOR float stayed at the surface for about $7 \mathrm{~h}$. According to the parking depths the floats are named here $\mathrm{f} 330, \mathrm{f} 350$ and $\mathrm{f} 400$.

\begin{tabular}{|c|c|c|c|}
\hline $\begin{array}{l}\text { Float type } \\
\text { named here }\end{array}$ & $\begin{array}{l}\text { Serial no. } \\
\text { Argo ID }\end{array}$ & $\begin{array}{l}\text { Deployment position; date } \\
\text { time period data delivery }\end{array}$ & Comment \\
\hline WRC APEX & $6013 / 3936$ & $08^{\circ} 04^{\prime} \mathrm{N}, 22^{\circ} 59^{\prime} \mathrm{W} ; 24$ April 2008 & Parking depth: $330 \mathrm{~m}$ \\
\hline f330 & 69005244 & June 2008-16 December 2009 & Max. depth:1000 m \\
\hline WRC APEX & $6014 / 3937$ & $08^{\circ} 11^{\prime} \mathrm{N}, 22^{\circ} 51^{\prime} \mathrm{W} ; 26$ April 2008 & Parking depth: $350 \mathrm{~m}$ \\
\hline $\mathrm{f} 350$ & 6900525 & 27 May 2008-6 May 2012 & Max. depth: $1000 \mathrm{~m}$ \\
\hline \multirow{2}{*}{$\begin{array}{l}\text { Martec PROVOR } \\
\mathrm{f} 400\end{array}$} & & $08^{\circ} 11^{\prime} \mathrm{N}, 22^{\circ} 51^{\prime} \mathrm{W} ; 26$ April 2008 & Parking depth: $400 \mathrm{~m}$ \\
\hline & 6900629 & 27 April 2008-24 January 2012 & Max. depth: $2000 \mathrm{~m}$ \\
\hline
\end{tabular}

2.2.4 assimilates all available data from hydrographic stations, expandable bathythermographs, and floats, but does not use satellite altimetry. In this version, hydrographic observations come from WOD09 (Boyer et al., 2009) using their standard level temperature and salinity data. Thus these data have been corrected for the drop-rate error as described by Levitus et al. (2009). Experiments with SODA show that applying the Levitus et al. (2009) drop-rate correction reduces much of the decadal variability observed in both the hydrographic observations and ocean reanalysis (Giese et al., 2011). The model results from this setup will be referred to as the SODA model in the following.

The SODA model mean flow field for the period 2001 to 2010 for the layers 50 to $200 \mathrm{~m}$ and 200 to $400 \mathrm{~m}$ (Fig. 2) will be used as background information on the mean circulation in the tropical eastern North Atlantic and for a comparison with the observed circulation features. The model results for October-November 2010 (Fig. S2) can be used for a detailed comparison to the October-November 2010 Meteor M83/1 measurements and the 2001 to 2010 mean velocity section at $23^{\circ} \mathrm{W}$ (Fig. 3) to investigate the depth distribution of the zonal currents. The SODA model velocity difference between the year 2009 and the mean 2001 to 2010 velocity at $23^{\circ} \mathrm{W}$ and $10^{\circ} \mathrm{N}$ (Fig. S3) is used to check the 2009 anomaly in the Guinea Dome.

\section{Results}

\subsection{Circulation in the low oxygen zone of the eastern tropical North Atlantic Ocean}

The SSHA along $23^{\circ} \mathrm{W}$ on 18 November 2009 reflects the large-sale upper ocean velocity in November 2009 (Fig. 4) with westward flow south of $\sim 5^{\circ} \mathrm{N}$, eastward flow between 5 and $11^{\circ} \mathrm{N}$ and both westward and eastward flow components north of $11^{\circ} \mathrm{N}$. The zonal velocity and oxygen distribution in November 2009 along $23^{\circ} \mathrm{W}$ (Fig. 4) shows enhanced oxygen content in the upper 250 to $300 \mathrm{~m}$ in the region of the two eastward NECC bands centered at about 4.5 and $8^{\circ} \mathrm{N}$. The westward flow component at $6-7^{\circ} \mathrm{N}$ carries oxygen-poor water in the 100 to $200 \mathrm{~m}$ depth range. Westward flow at $12^{\circ} \mathrm{N}$ north of the center of the Guinea Dome (flow reversal at $23^{\circ} \mathrm{W}$ at about $9^{\circ} \mathrm{N}$ in November 2009) recirculates oxygen-rich nNECC water westwards at a depth of about $200 \mathrm{~m}$, but carries oxygen-poor water westward in the OMZ depth range (Fig. 4). The strongest oxygen minimum is located slightly above the $27.1 \mathrm{~kg} \mathrm{~m}^{-3}$ isopycnal layer, hence in the lower part of the Central Water $\left(\sigma_{\theta}=25.8\right.$ and $27.1 \mathrm{~kg} \mathrm{~m}^{-3}$ ).

As seen in the November 2009 velocity distribution at $23^{\circ} \mathrm{W}$, most current bands from the near-surface layer reach down to the OMZ core, especially the nNECC and the current bands north of $10^{\circ} \mathrm{N}$. The NECC at about $4.5^{\circ} \mathrm{N}$ is sometimes weaker and can even reverse to westward flow below $300 \mathrm{~m}$ in the mean of several ADCP sections along $23^{\circ} \mathrm{W}$ (Brandt et al., 2015; their Fig. 6). The eastward flow component south of the Cape Verde Islands called the Cape Verde Current by Peña-Izquierdo et al. (2015) centered at about $13^{\circ} \mathrm{N}$ at $23^{\circ} \mathrm{W}$ is weak in November 2009 compared to the mean $23^{\circ} \mathrm{W}$ section (Brandt et al., 2015), but nevertheless reaches to at least $500 \mathrm{~m}$ depth. A similar flow direction in the upper ocean, as well as in the OMZ layer, can be seen in the mean velocity distribution at $23^{\circ} \mathrm{W}$ and at $18^{\circ} \mathrm{N}$ east of $26^{\circ} \mathrm{W}$ (Brandt et al., 2015; their Figs. 6 and 5), and in single velocity sections at $38^{\circ} \mathrm{W}$ (Urbano et al., 2008; their Fig. 5), at $28^{\circ} \mathrm{W}$ (Stramma et al., 2008b; their Fig. 3) and at $11^{\circ} \mathrm{N}$ east of $22^{\circ} \mathrm{W}$ (Stramma et al., 2005; their Fig. 11). Also, the SODA 10 -year mean velocity section at $23^{\circ} \mathrm{W}$ (Fig. 3) shows the current bands except for the NECC at $4-5^{\circ} \mathrm{N}$ to reach to depth of $800 \mathrm{~m}$. The eastward flow south of the Cape Verde Islands is found in two cores located at about 12 and $14^{\circ} \mathrm{N}$, similar to the mean $23^{\circ} \mathrm{W}$ section (Brandt et al., 2015).

Except for the sections at 18 and $11^{\circ} \mathrm{N}$, there is not much information about the meridional circulation at the OMZ layer, and schematics often show only zonal flow components (e.g., Brandt et al., 2015). Mittelstaedt (1983) showed that the cyclonic circulation cell in the surface layer between the Cape Verde Islands and the African continent varies in size related to the wind. The circulation has a weaker south- 


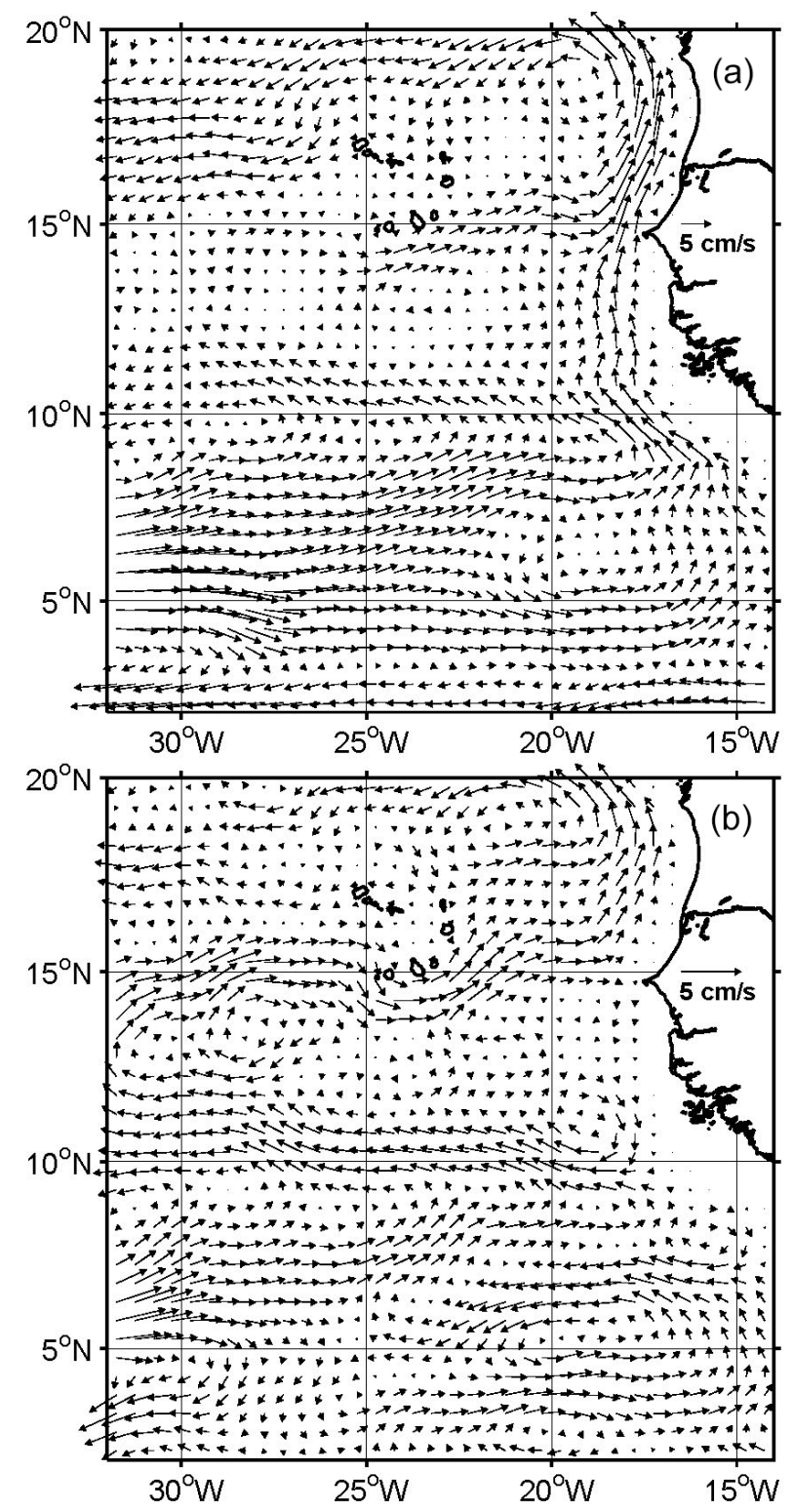

Figure 2. SODA model mean circulation for the period 2001 to 2010 for the layers 50 to $200 \mathrm{~m}$ (a) and 200 to $400 \mathrm{~m}$ (b).

ward extent of the center of the cyclonic cell in winter, reaching to about $15^{\circ} \mathrm{N}$, in contrast to summer when it reaches to about $12^{\circ} \mathrm{N}$. Several sections near the African shelf were made in October 2010 (Fig. 5). At $15^{\circ} \mathrm{N}$ the northward currents are strongest in the upper ocean, but most of the currents reach into the OMZ layer. The SODA results from the 50 to $200 \mathrm{~m}$ layer and 200 to $400 \mathrm{~m}$ layer for the 10 -year mean circulation (Fig. 2) as well as for October-November 2010 (Fig. S2) show that this is the southernmost part of the cyclonic circulation cell, with a flow contribution from the west. At $12.5^{\circ} \mathrm{N}$ a cyclonic circulation cell with a core of southward flow at 19.5 to $20^{\circ} \mathrm{W}$ and northward flow at 18 to $18.5^{\circ} \mathrm{W}$ (Fig. 5) was observed. The SODA velocities for

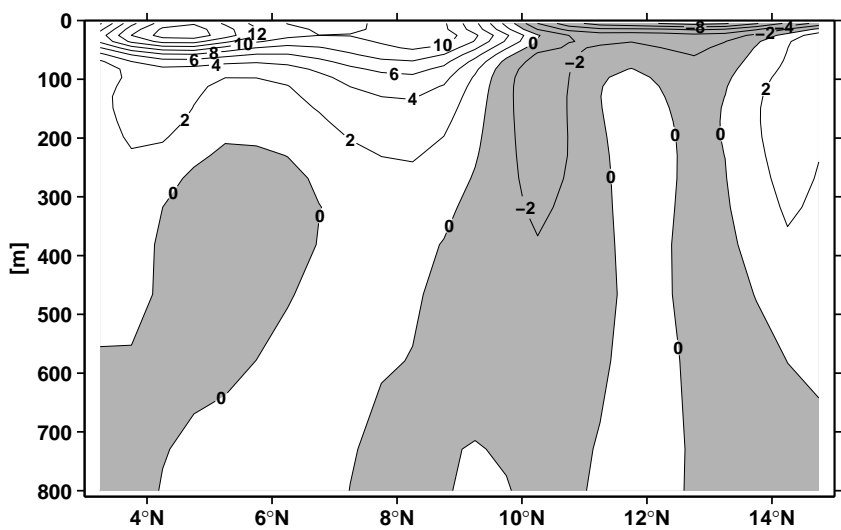

Figure 3. SODA model mean velocity section in $\mathrm{cms}^{-1}$ for the period 2001-2010 along $23^{\circ} \mathrm{W}$ (positive eastward).
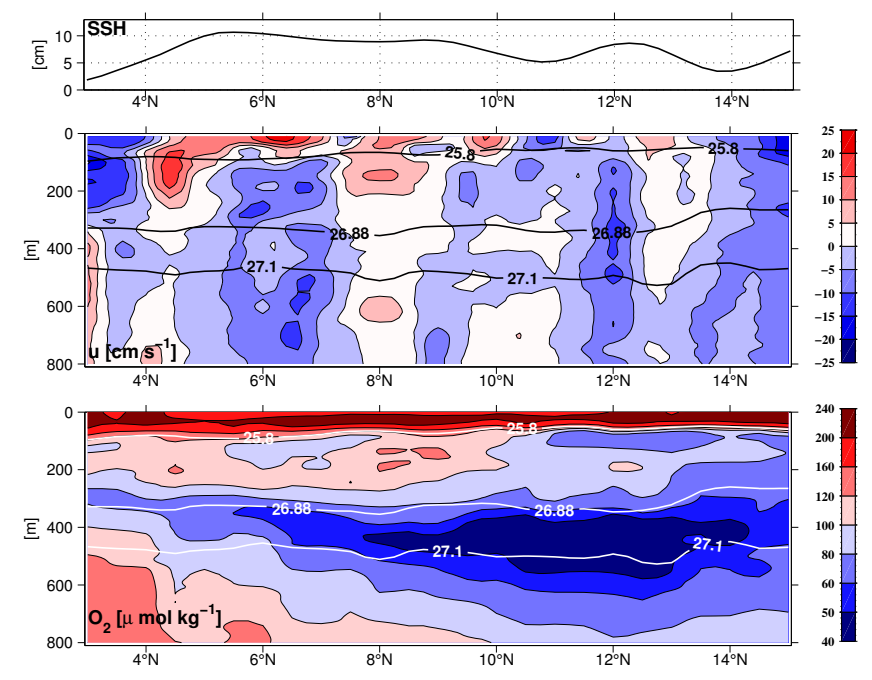

Figure 4. Sea surface height anomaly on 18 November 2009 in cm (top), zonal velocity component 15 to 21 November 2009 in $\mathrm{cm} \mathrm{s}^{-1}$ (middle) and oxygen content in $\mu \mathrm{mol} \mathrm{kg}^{-1}$ (bottom) at $23^{\circ} \mathrm{W}$. Selected isopycnals $\sigma_{\theta}=25.8$ and $27.1 \mathrm{~kg} \mathrm{~m}^{-3}$ for Central Water boundaries and $\sigma_{\theta}=26.88 \mathrm{~kg} \mathrm{~m}^{-3}$ for the tracer release density are included as black (middle panel) and white (lower panel) lines.

the same time (Fig. S2) indicate a second cyclonic cell located south of the cyclonic cell east of the Cape Verde Islands in October-November 2010. The northward flow at $10^{\circ} \mathrm{N}$ at 18.5 to $19^{\circ} \mathrm{W}$ and the southward flow west of $19.5^{\circ} \mathrm{W}$ seem to be the southern component of the cyclonic cell observed at $12.5^{\circ} \mathrm{N}$. The southward flow at about $21^{\circ} \mathrm{W}$ at $8^{\circ} \mathrm{N}$ (Fig. 5) could be a recirculation branch of the nNECC as in the SODA flow field during October-November 2010 (Fig. S2, bottom), while the meridional flow components in the $8^{\circ} \mathrm{N}$ section east of $20^{\circ} \mathrm{W}$ are quite weak. The second cyclonic cell located at about $12.5^{\circ} \mathrm{N}$ in October 2010 is an exceptional situation, in the long-term mean the SODA velocities show a westward excursion of the 200 to $400 \mathrm{~m}$ layer in this region. The existing zonal and meridional ADCP ve- 

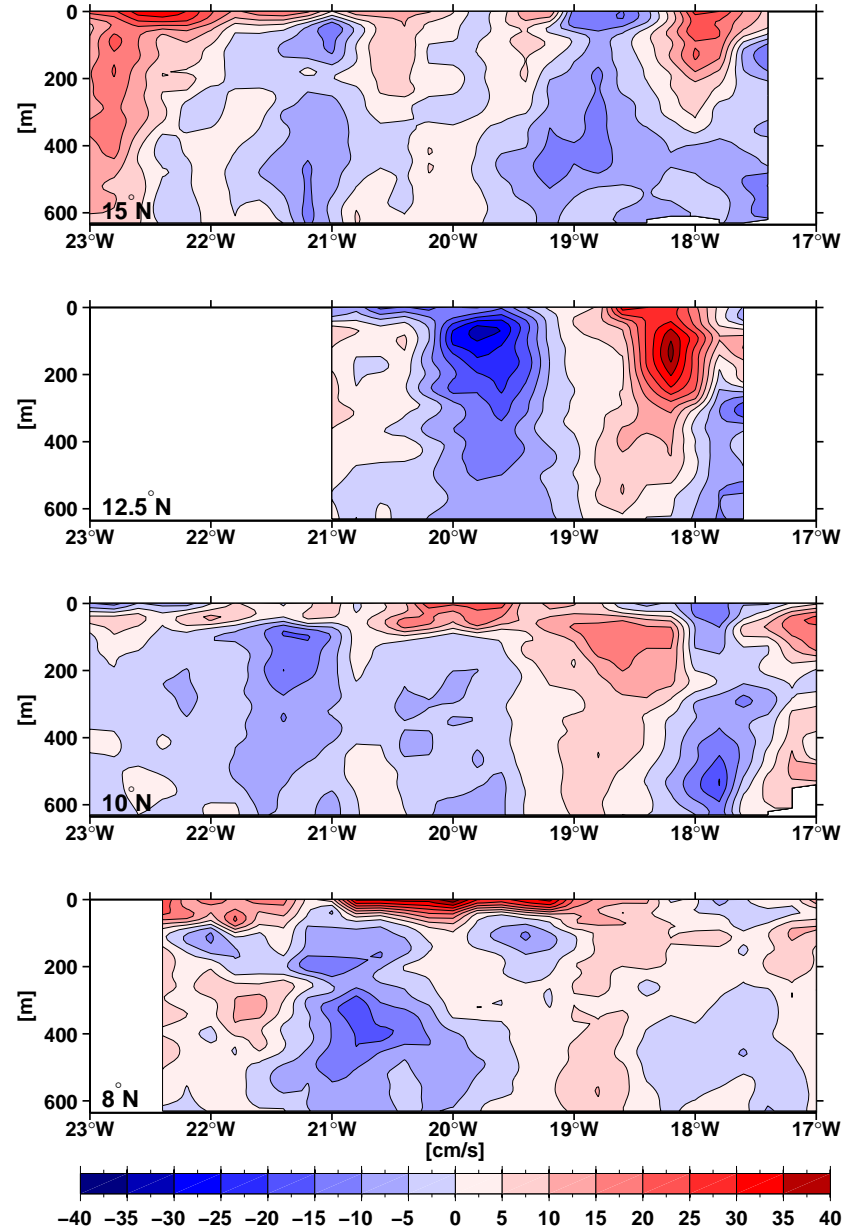

Figure 5. Meridional velocity component in $\mathrm{cm} \mathrm{s}^{-1}$ (positive northward) at about $15^{\circ} \mathrm{N}$ east of $23^{\circ} \mathrm{W}$, at $12.5^{\circ} \mathrm{N}$ east of $21^{\circ} \mathrm{W}$, at $10^{\circ} \mathrm{N}$ east of $23^{\circ} \mathrm{W}$, and at $8^{\circ} \mathrm{N}$ east of $22.4^{\circ} \mathrm{W}$ and west of $17^{\circ} \mathrm{W}$, all measured in October 2010 (cruise tracks can be seen in Fig. 11).

locity sections and the SODA velocity distribution show that flow in the low oxygen layer generally mirrors the circulation of the near-surface layer.

The observed velocity distribution and measured oxygen values at $350 \mathrm{~m}$ depth in November and December 2009 (Fig. 6) are quite variable, especially on the equatorial side of the OMZ. This is in agreement with the SODA flow field for October-November 2010 (Fig. S2), where the flow is also highly variable. The oxygen distribution measured in November and December 2009 at $350 \mathrm{~m}$ near $30^{\circ} \mathrm{W}$ between 8 and $10^{\circ} \mathrm{N}$ is generally higher compared to the CARS climatology; however, it is lower for most measurements east of $30^{\circ} \mathrm{W}$. In the $\mathrm{OMZ}$ north of $10^{\circ} \mathrm{N}$, measured oxygen levels are mostly lower at the boundaries of the OMZ than climatological ones. Near the climatological OMZ core at about $12.5^{\circ} \mathrm{N}, 20^{\circ} \mathrm{W}$, measured oxygen values are higher just south of $12.5^{\circ} \mathrm{N}$, and are either in agreement with or lower than climatology to the north of $12.5^{\circ} \mathrm{N}$. The lowest

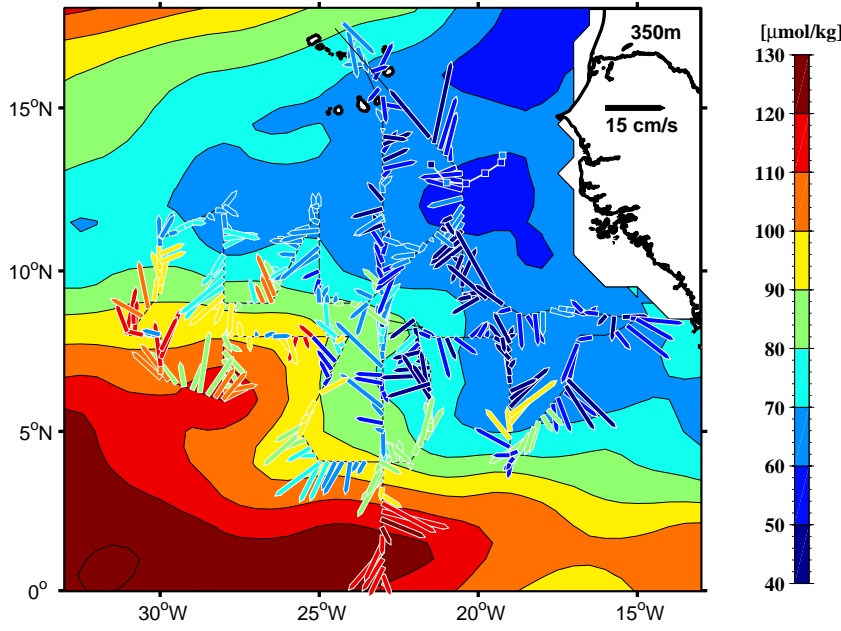

Figure 6. Horizontal distribution of ADCP velocity vectors converted to $350 \mathrm{~m}$ depth recorded in November and December 2009 with current vectors colored with oxygen (in $\mu \mathrm{mol} \mathrm{kg} \mathrm{kg}^{-1}$ ) of the accompanying CTD oxygen measurements at this depth. The oxygen distribution of the background field is from CARS 2009 climatology (Ridgway et al., 2002) for the mean of the November and December distribution at $350 \mathrm{~m}$ depth. The float track (white line) and surfacing location (white squares) drifting at $350 \mathrm{~m}$ depth and the oxygen measured by the float at $350 \mathrm{~m}$ depth (color in the square) are shown for the months November and December 2009.

oxygen concentrations in the climatology at $350 \mathrm{~m}$ depth are located in the region of the cyclonic circulation cells between the Cape Verde Islands and Africa, indicative of reduced water renewal in these cyclonic circulation cells. The float at $350 \mathrm{~m}$ depth (f350) moved westward north of the OMZ core in December 2009 (Fig. 6) and measured oxygen values from this float agree well with climatology. The northward shift of the float at about $12.5^{\circ} \mathrm{N}, 21^{\circ} \mathrm{W}$ seems to be connected to an increased SSHA gradient connected to a strengthening of the high and low SSHA at this location (Supplement Movie M1 for 1 December 2009). Because the NECC is weaker in boreal winter, the variable flow components south of $10^{\circ} \mathrm{N}$ might be related to a weakened NECC, although the oxygen distribution indicates an oxygen supply to the OMZ, especially west of $20^{\circ} \mathrm{W}$. In boreal winter the core of the Guinea Dome should be located at $10.5^{\circ} \mathrm{N}, 22^{\circ} \mathrm{W}$; however, according to the velocity distribution at $23^{\circ} \mathrm{W}$, the Guinea Dome center seems to be still south of $10.5^{\circ} \mathrm{N}$. While the nNECC south of the Guinea Dome is weak and variable, the westward flow with low oxygen content north and east of the Guinea Dome center is more obvious (Fig. 6).

In general lower oxygen levels in late 2009 as compared to climatology dominate in the OMZ region (Fig. 6), and are probably related to the observed trend of deoxygenation in the eastern tropical North Atlantic (region $10-14^{\circ} \mathrm{N}$, $20-30^{\circ} \mathrm{W}$ ) from 1960 to 2007 (Stramma et al., 2008a). The oxygen trend in the region $10-14^{\circ} \mathrm{N}, 20-30^{\circ} \mathrm{W}$ computed as by Stramma et al. (2008a) was extended with ad- 

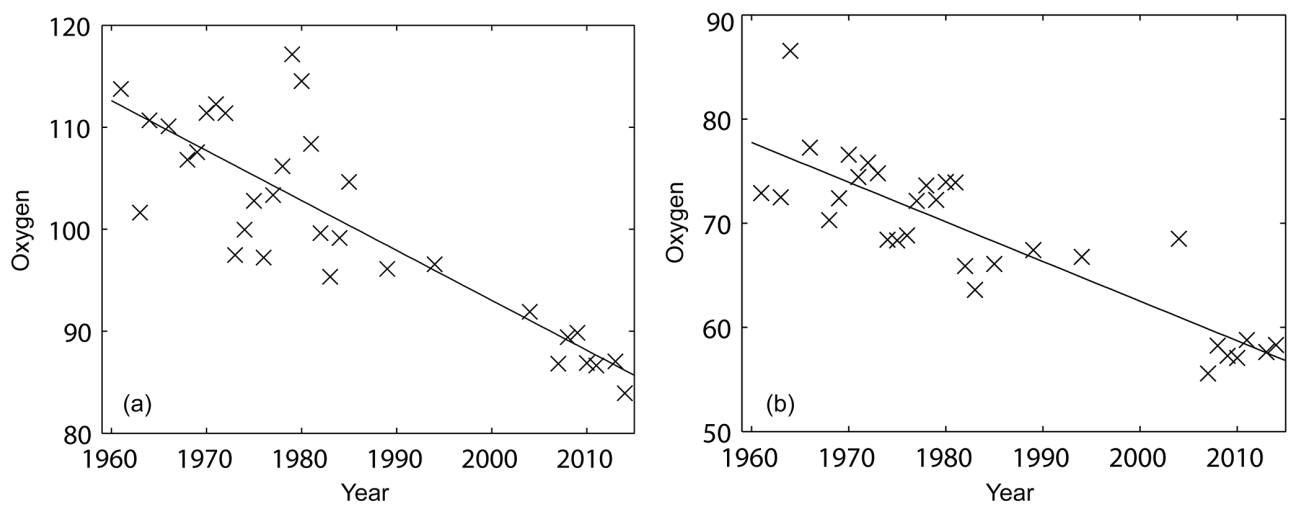

Figure 7. Mean dissolved oxygen concentration time series $(\mu \mathrm{mol} \mathrm{kg}-1)$ for the area $10-14^{\circ} \mathrm{N}, 20-30^{\circ} \mathrm{W}$ with a fitted linear trend and $95 \%$ confidence interval for (a) $100-300 \mathrm{~m}\left(-0.49 \pm 0.16 \mu \mathrm{mol} \mathrm{kg}^{-1} \mathrm{yr}^{-1}\right)$ and (b) 300-700 $\mathrm{m}\left(-0.35 \pm 0.16 \mu \mathrm{mol} \mathrm{kg}^{-1} \mathrm{yr}^{-1}\right)$.

ditional shipboard measurements along $23^{\circ} \mathrm{W}$ from cruises in November 2008, November 2009 and October 2010 as well as from March 2008, June 2011, June 2013 and April 2014. Several measurements in the area within a calendar year were averaged to derive a single oxygen value per year. Some improvements in the computation method were made; for example, no interpolation was made for years without measurements. The computed trend confirms the deoxygenation trend in the upper OMZ layer at 100 to $300 \mathrm{~m}$ depth up to the year 2014 with a linear trend of $-0.49 \pm 0.16 \mu \mathrm{mol} \mathrm{kg}^{-1} \mathrm{yr}^{-1}$ (Fig. 7a). A similar oxygen decrease for recent years was described for the 150 to $300 \mathrm{~m}$ layer (Brandt et al., 2015). For the deeper layer (300 to $700 \mathrm{~m}$ ) the linear trend of $-0.34 \pm 0.13 \mu \mathrm{mol} \mathrm{kg}^{-1} \mathrm{yr}^{-1}$ up to the year 2007 (Stramma et al., 2008a) slightly increased to $-0.38 \pm 0.09 \mu \mathrm{mol} \mathrm{kg}-1 \mathrm{yr}^{-1}$ when extended to 2014 (Fig. 7b). The 300 to $700 \mathrm{~m}$ layer shows an increase in oxygen in recent years (Fig. 7b) as described by Brandt et al. (2015); however, the measured lower oxygen content in recent years than predicted from the 1960 to 2007 trend nevertheless leads to the slightly increased trend.

\subsection{Float measurements}

The three floats deployed with a parking depth at 330, 350 and $400 \mathrm{~m}$ at the same location (Table 1) show quite different flow paths (Fig. 8). Especially the floats drifting at 350 and $400 \mathrm{~m}$ depth that were deployed at the same location within the eastward flowing nNECC (Fig. 4) and same time show quite different flow trajectories (Fig. 8). According to the mean velocity distribution at $23^{\circ} \mathrm{W}$ (e.g., Brandt et al., 2010, 2015), the deployment site at about $8^{\circ} 10^{\prime} \mathrm{N}$ is in a region of strong eastward flow in the upper 100-200 $\mathrm{m}$ of the nNECC, weak eastward flow below $200 \mathrm{~m}$ depth and weak westward flow at $100-1000 \mathrm{~m}$ depth to the south of about $7.5-8^{\circ} \mathrm{N}$.

All floats stayed first in the nNECC or the region south of the nNECC. The float at $330 \mathrm{~m}$ depth (f330) first moved southeastward through 22 December 2008 and then moved

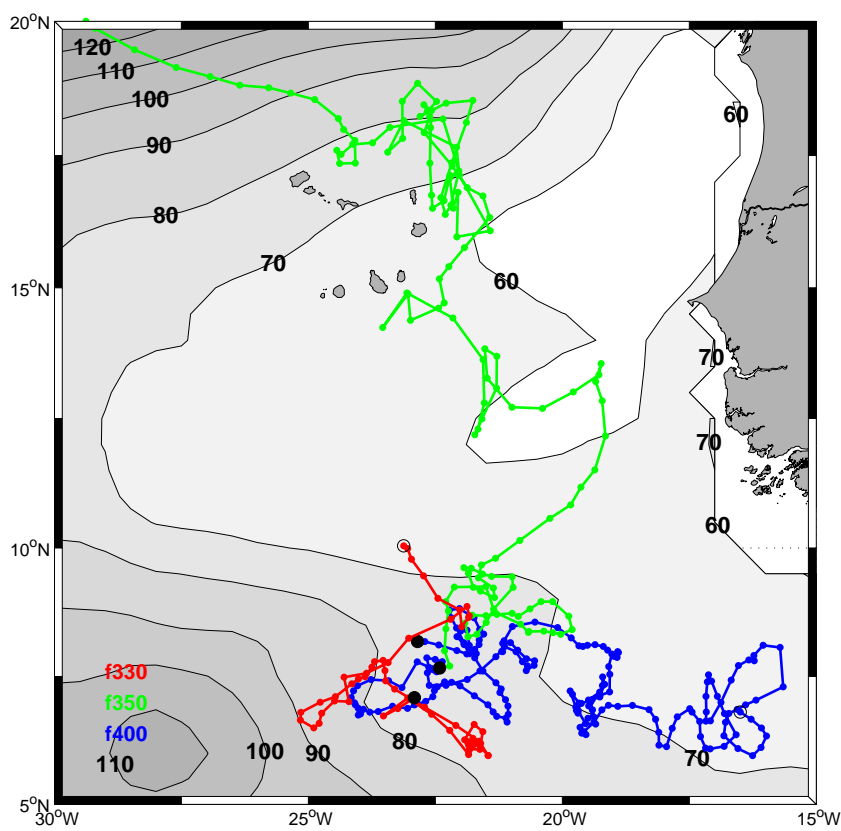

Figure 8. Annual mean climatological oxygen distribution (grey shaded contours, $\mu \mathrm{mol} \mathrm{kg}{ }^{-1}$ ) at $350 \mathrm{~m}$ depth from CARS $2009 \mathrm{cli}-$ matology (Ridgway et al., 2002) with trajectories (in color) of three floats deployed in April 2008 (red 330 m (f330), green 350 m (f350), blue $400 \mathrm{~m}$ (f400)). The first measurement cycle is shown as solid dot and the last cycle as open circle (Table 1).

southwestward through 31 May 2009 before it started to move northeastward crossing the nNECC region to $10^{\circ} \mathrm{N}$ where the float stopped working in late December 2009. The float at $350 \mathrm{~m}$ depth moved northeastward through 25 October 2008, then reversed direction westward and northward, and it crossed $10^{\circ} \mathrm{N}$ on 10 August 2009. The float at $400 \mathrm{~m}$ depth stayed its entire lifetime of 3.75 years in the region between 6 and $9^{\circ} \mathrm{N}$ between the NEUC and the nNECC. Annual reversals were strongest in the western part of the f400 track, when it moved southeastward through 9 Decem- 
ber 2008 and then westward up to 9 June 2009, before it mainly moved eastward. The mean eastward velocity between the deployment location and the location of the final data transmission was $0.6 \mathrm{~cm} \mathrm{~s}^{-1}$.

In the region 6 to $9^{\circ} \mathrm{N}$ and 25 to $20^{\circ} \mathrm{W}$ the floats moved eastward between about May and November and westward in late winter and spring. In an early investigation of the NECC, a strong NECC with two eastward cores in July to September was observed, while generally near-surface westward flow is found during March to May (Richardson and Reverdin, 1987). When separating the surface drift of the three floats for the time at the surface to transmit data and for the subsurface drift, the surface drift was eastward from mid-May to December and westward from January to mid-May with an annual mean eastward velocity of $9 \mathrm{~cm} \mathrm{~s}^{-1}$, while the subsurface flow was weak year-round with a mean eastward component of $0.02 \mathrm{~cm} \mathrm{~s}^{-1}$. Hence the eastward shift of the floats, especially of float $\mathrm{f} 400$, is mainly due to the seasonal surface signal of the NECC and is not caused by an eastward drift at the parking depth near the OMZ core. This is in agreement with ADCP velocity observations that show the flow below the NECC is weak, or even westward, as well as with the velocity field of the 10-year mean SODA data (Fig. 2).

The floats were used to determine the velocity at the surface and at the parking depth. The float at $400 \mathrm{~m}$ depth, with a mean eastward flow of $0.6 \mathrm{~cm} \mathrm{~s}^{-1}$, stayed at the surface for about $7 \mathrm{~h}$ of the 7-day diving cycle, which leads to an eastward flow component of $14.4 \mathrm{~cm} \mathrm{~s}^{-1}$ if the float had stayed at the surface for the entire time. This value is higher than the $9 \mathrm{~cm} \mathrm{~s}^{-1}$ eastward flow computed for the three floats at the surface when they were located south of $9^{\circ} \mathrm{N}$, but weaker compared to the mean geostrophic eastward component of $20 \mathrm{~cm} \mathrm{~s}^{-1}$ at $6^{\circ} \mathrm{N}$ between 15 and $40^{\circ} \mathrm{W}$ for the period 1993 to 2009 computed for the core position of the NECC (Hormann et al., 2012).

The complete record of spreading and vertical oxygen distribution of float $\mathrm{f} 350$ (Fig. 9) shows northward movement through the low oxygen layer of the OMZ into the oxygenated North Atlantic subtropical gyre. This float stayed south of $10^{\circ} \mathrm{N}$ for more than a year, but in July 2009 it suddenly moved rapidly to the north. At the same time a strong SSHA appeared in the region between the two NECC branches (Supplement Movie M1), which may have triggered the northward displacement of the float. The float drifted northward from $10^{\circ} \mathrm{N}$ on 10 August 2009 to $14.9^{\circ} \mathrm{N}$ on 28 March 2010 and crossed the OMZ with a mean speed of about $2.75 \mathrm{~cm} \mathrm{~s}^{-1}$. While crossing the OMZ, the drift of this float had a weak southwestward component; hence, the entire northward drift across the OMZ of the float took place at the subsurface layer near the parking depth of $350 \mathrm{~m}$. Unfortunately the float $\mathrm{f} 330$ stopped operating at the end of 2009 when it moved northward into the OMZ; however, the f330 northward movement occurred in the subsurface, while the surface drift was toward the east.
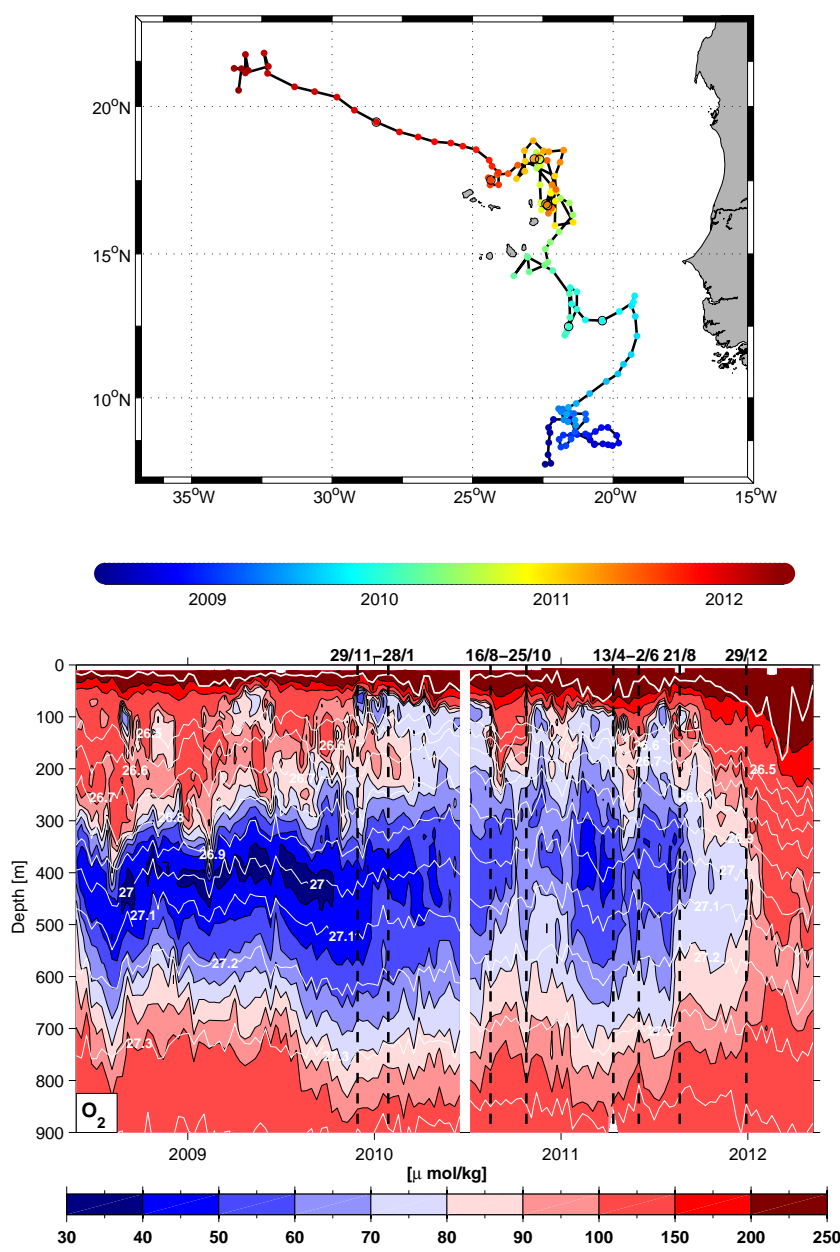

Figure 9. Measurements of float $\mathrm{f} 350$ in the tropical eastern North Atlantic between April 2008 and May 2012 with float path (color coded) in time (top) and oxygen distribution (bottom) in $\mu \mathrm{mol} \mathrm{kg} \mathrm{kg}^{-1}$ (color) vs. time in the upper $900 \mathrm{~m}$; density contours are marked in white, the mixed layer depth defined for the depth where the density is $0.125 \mathrm{~kg} \mathrm{~m}^{-3}$ larger than at the surface as the thick white line. Some dates bounding anomalous oxygen distributions are marked on top of the figure.

The float at $350 \mathrm{~m}$ moved in a cyclonic track around the core of the OMZ. This cyclonic northward drift in summer 2009 could be caused by an anomalously strong Guinea Dome event. The Guinea Dome strength is described as connected to the Atlantic Meridional Mode (AMM; Doi et al., 2010). The AMM is a climate mode associated with the cross-equatorial meridional gradient of the sea surface temperature (SST) anomaly in the tropical Atlantic (Doi et al., 2010) with a negative AMM defined by a negative/positive SST anomaly in the Northern/Southern Hemisphere (Foltz et al., 2012). During the preconditioning phase of an AMM in late fall of the previous year, the dome is weaker with enhanced mixed layer depth existing in the dome region. As a result, a positive SST 
anomaly appears in early winter. In the following spring the wind-evaporation-SST positive feedback is associated with anomalous northward migration of the inter-tropical convergence zone (ITCZ) leading to stronger Ekman upwelling and colder subsurface temperatures in the dome region in summer (Doi et al., 2010) and hence to a stronger circulation around the Guinea Dome. Using monthly mean SST values of the AMM (http://www.esrl.noaa.gov/psd/data/timeseries/ monthly/AMM/ammsst.data), the temperature was about $2{ }^{\circ} \mathrm{C}$ higher during the preconditioning time from September to December 2008 and cooler, with an anomaly of up to $-5.3^{\circ} \mathrm{C}$, in the period from February to June 2009 . The SODA velocity anomalies for 2009 at $23^{\circ} \mathrm{W}$ and $10^{\circ} \mathrm{N}$ (Fig. S3 in the Supplement) confirm a stronger cyclonic circulation around the Guinea Dome located at about $10^{\circ} \mathrm{N}$, $23^{\circ} \mathrm{W}$ below the mixed layer. A strong AMM event in 2009 was also described using measurements at two moorings located at $4^{\circ} \mathrm{N}, 23^{\circ} \mathrm{W}$ and $12^{\circ} \mathrm{N}, 23^{\circ} \mathrm{W}$ by Foltz et al. (2012).

The anticyclonic movement of the float $\mathrm{f350}$ in the OMZ at about $22^{\circ} \mathrm{W} 12$ to $14^{\circ} \mathrm{N}$ (Fig. S4) between 29 November 2009 and February 2010 shows a weak upward shift of the isopycnals in the upper $50 \mathrm{~m}$ and weak downward shift of the isopycnals down to $350 \mathrm{~m}$ in December 2009. This is a weak signature of an anticyclonic mode water eddy. Most striking during this time is the shallow oxygen minimum at $100 \mathrm{~m}$ depth between 29 November 2009 and 28 January 2010. Animation of the float location relative to the SSHA (Supplement Movie M1) indicates some anticyclonic structure in the SSHA field, although positive SSHA moves rapidly to the west. North of the Cape Verde Islands, low oxygen layers just below the mixed layer seem to be created by cyclonic and anticyclonic mode water eddies (Karstensen et al., 2015). The low oxygen concentration at 50 to $100 \mathrm{~m}$ depth in November 2009 might be created by a mode water eddy, although the second oxygen minimum in January does not show a mode water density structure. A comparison of low oxygen periods near $100 \mathrm{~m}$ depth or the higher oxygen content in the upper $200 \mathrm{~m}$ (Fig. S4) with the SSHA (Supplement Movie M1) and the density distribution did not provide convincing evidence for eddy signatures. Mode water eddies might have a weak surface SSHA signature and might be missed in altimeter data; however, as only a few mode water type signatures were observed in the measurements, a large influence on the OMZ by mode water eddies is not expected.

The high oxygen layer that extends down to $200 \mathrm{~m}$ present before December 2009 gradually reduces along the northward float track in the following months and oxygen of less than $70 \mu \mathrm{mol} \mathrm{kg}^{-1}$ dominates the region near the Cape Verde Islands through July 2011 (Fig. 9), although oxygen of more than $100 \mu \mathrm{mol} \mathrm{kg}{ }^{-1}$ down to $200 \mathrm{~m}$ was measured in August to October 2010 and April to early June 2011. The SSHA movie shows a fast passage of a SSHA maximum, indicating an anticyclonic feature (Movie M1). The core of the oxygen minimum was continuously near the isopycnal $27.0 \mathrm{~kg} \mathrm{~m}^{-3}$ through December 2011 and shifts deeper to $600 \mathrm{~m}$ depth and the isopycnal $27.15 \mathrm{~kg} \mathrm{~m}^{-3}$ at about $18^{\circ} \mathrm{N}$ (Fig. 9) when drifting northwestward into the NEC of the subtropical gyre. The northwestward drift of the float north of the Cape Verde Islands (Fig. 9) from mid-2011 to May 2012 is a combination of a westward flow component at the surface and a northwestward flow component in the subsurface.

\subsection{Tracer spreading}

The tracer distribution and float paths represent an integral effect of the velocity field since deployment, while ADCP surveys yield velocity snapshots influenced by eddies, tides and internal waves. Nevertheless it is interesting to investigate how different results obtained by the various methods might be. Spreading of the tracer $\left(\mathrm{CF}_{3} \mathrm{SF}_{5}\right)$ deployed in April 2008 at $\sim 8^{\circ} \mathrm{N}, 23^{\circ} \mathrm{W}$ on the density surface $\sigma_{\theta}=26.88 \mathrm{~kg} \mathrm{~m}^{-3}$ at about $330 \mathrm{~m}$ depth through December 2009 was investigated using rosette water samples collected at CTD stations of Meteor cruise M80/2 (Banyte et al., 2013). Close to the tracer deployment target density, tracer samples were taken with $10 \mathrm{~m}$ spacing. The spatially maximum tracer value distribution was close to the target density in December 2009 in relation to the ADCP velocity at the isopycnal $\sigma_{\theta}=26.88 \mathrm{~kg} \mathrm{~m}^{-3}$ and shows the tracer spreading in the ETNA (Fig. 10). The mean depth of the maximum tracer concentration in December 2009 was $314 \mathrm{~m}$. The largest tracer concentrations were measured east of the deployment location at locations where the ADCP velocity in December 2009 is toward the east in agreement with the mean eastward flow between $\sim 7.5$ and $9.5^{\circ} \mathrm{N}$ in the mean $23^{\circ} \mathrm{W}$ section (Brandt et al., 2015; their Fig. 6c). This eastward spreading differs in comparison to our floats, which showed only weak eastward velocity components at the subsurface layer. Investigating a larger float data set, it is found that the NECC eastward component is strongest at the surface. However, at the 200 and $1000 \mathrm{~m}$ depth levels there is also an eastward component (Rosell-Fieschi et al., 2015; their Fig. 7). Our three floats may underestimate the mean eastward spreading of the tracer during periods of westward flow component. One reason could be that the floats drift at a greater depth than the mean tracer maximum depth at $314 \mathrm{~m}$. The mean zonal velocity components from about 25 ADCP velocity ship sections at about $23^{\circ} \mathrm{W}$ (Brandt et al., 2015) show that below $200 \mathrm{~m}$ depth there is a westward flow between 5.5 and $7.5^{\circ} \mathrm{N}$ leading to an enhanced westward component for the floats when located south of $7.5^{\circ} \mathrm{N}$.

To the south of the deployment location, large tracer signals are found at about $6^{\circ} \mathrm{N}$, where the ADCP velocities are directed westward and indicate recirculation of the lower part of the NECC or the nNECC to the west or the influence of waves in November-December 2009. The higher tracer concentrations north of $9^{\circ} \mathrm{N}$ are connected to ADCP velocities directed westward and indicate a cyclonic flow around the Guinea Dome in agreement with the westward flow be- 


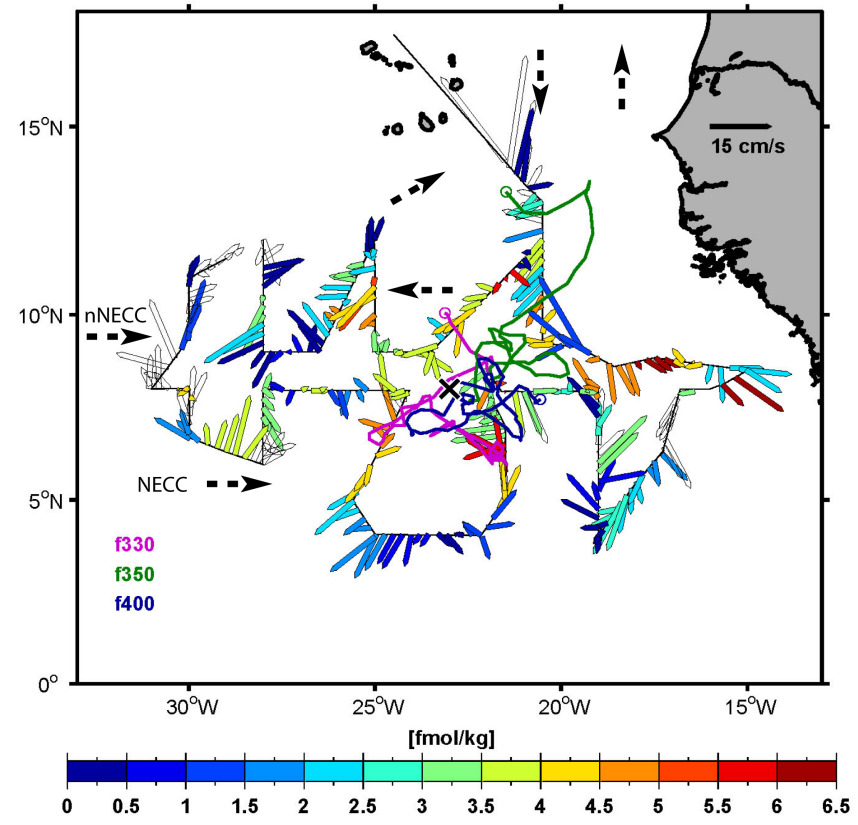

Figure 10. Horizontal distribution of ADCP velocity vectors converted to the isopycnal $\sigma_{\theta}=26.88 \mathrm{~kg} \mathrm{~m}^{-3}$ recorded in November and December 2009 with current vectors interpolated on $0.25^{\circ}$ intervals colored with the maximum tracer $\left(\mathrm{CF}_{3} \mathrm{SF}_{5}\right)$ concentration (in fmol kg-1) of the nearest CTD bottle measurements near this isopycnal. Open arrows only show velocity information because no tracer was sampled. The black $\times$ with a white frame at $\sim 8^{\circ} \mathrm{N}$, $23^{\circ} \mathrm{W}$ shows the deployment location where the tracer and the three floats were deployed in April 2008. The three float tracks for the period April 2008 to December 2009 are included as red, green and blue curves with a circle for the December 2009 location. The main current field is indicated by dashed black arrows.

tween 9.5 and $12^{\circ} \mathrm{N}$ in the mean $23^{\circ} \mathrm{W}$ section (Brandt et al., 2015). Also near $12^{\circ} \mathrm{N}, 21^{\circ} \mathrm{W}$, where the float showed a westward flow at the time of the ship passage, the ADCP velocity is directed westward with higher tracer signals.

The three floats deployed together with the tracer in April 2008 at the same location $\left(\sim 8^{\circ} \mathrm{N}, 23^{\circ} \mathrm{W}\right)$ and similar depth levels show paths in the region where the largest tracer signals were observed (Fig. 10). At 6 to $7^{\circ} \mathrm{N}$ the floats have a westward drift and the tracer signal is large. The ADCP flow field at 6 to $7^{\circ} \mathrm{N}$ in December 2009 is directed southwestward; hence, the flow field in December 2009 agrees with the long-term signal of the tracer spreading. North of $8^{\circ} \mathrm{N}$ the floats have mainly an eastward drift and the strongest tracer signals were measured east of the deployment site, although further east than the floats moved during the time period up to December 2009. However, the float at $400 \mathrm{~m}$ depth had a stronger eastward component after December 2009 and reached east to almost $15^{\circ} \mathrm{W}$, similar to where the large tracer signal was measured. The float at $350 \mathrm{~m}$ that experienced the cyclonic circulation around the Guinea Dome was close to the ship section near $13^{\circ} \mathrm{N}, 21^{\circ} \mathrm{W}$ in December 2009

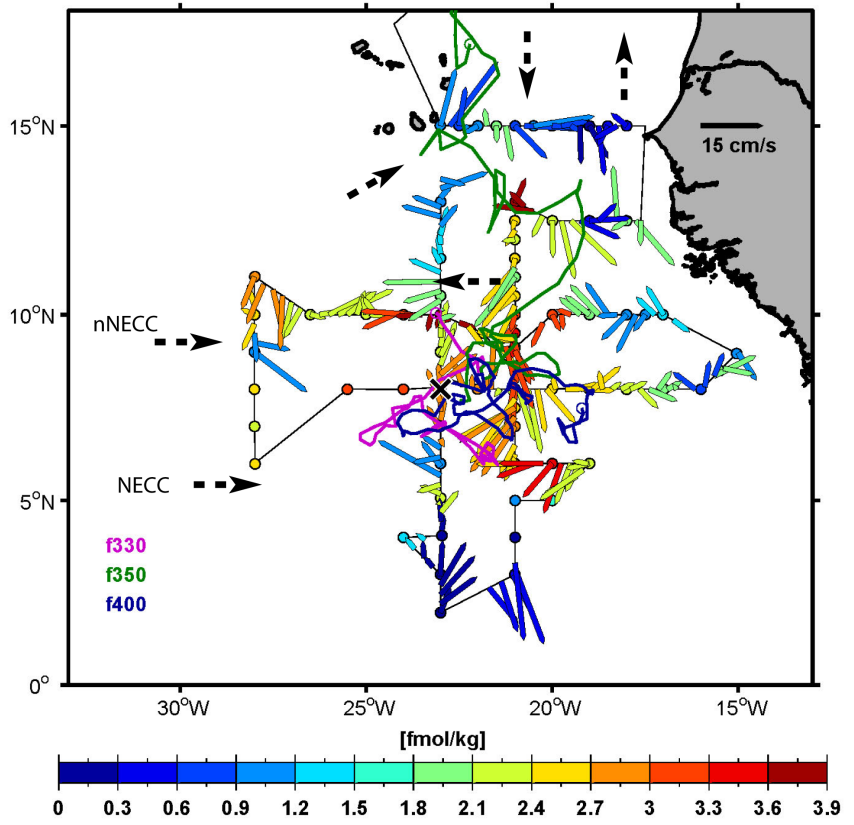

Figure 11. Horizontal distribution of ADCP velocity vectors converted to the isopycnal $\sigma_{\theta}=26.88 \mathrm{~kg} \mathrm{~m}^{-3}$ recorded in OctoberNovember 2010 with current vectors interpolated on $0.25^{\circ}$ intervals colored with the maximum tracer $\left(\mathrm{CF}_{3} \mathrm{SF}_{5}\right)$ concentration (in fmol kg-1) of the nearest CTD bottle measurements near this isopycnal. Colored dots show the maximum tracer at all tracer measurement locations even if no ADCP measurements are available. The black $\times$ with a white frame at $\sim 8^{\circ} \mathrm{N}, 23^{\circ} \mathrm{W}$ shows the deployment location where the tracer and the three floats were deployed in April 2008. The three float tracks for the period April 2008 to November 2010 are included as red, green and blue curves with a circle for the November 2010 location. Float $\mathrm{f} 330$ is shown through the transmission end on 16 December 2009 at $10.04^{\circ} \mathrm{N}, 23.12^{\circ} \mathrm{W}$ as a red curve. The main current field is indicated by dashed black arrows. Please note that the tracer color scale is different to the color scale in Fig. 10.

with a westward component in agreement with the westward ADCP velocity component and the enhanced tracer signal in the ship measurements.

The tracer distribution in October-November 2010 (Fig. 11), nearly 1 year later, shows reduced maximum tracer concentrations due to further spreading of the tracer by lateral diffusivity or mesoscale eddy diffusion (Banyte et al., 2013; Gnanadesikan et al., 2013; Hahn et al., 2014) and diapycnal mixing (Banyte et al., 2012). Nevertheless, the maximum tracer signal confirms the circulation features described for December 2009. The largest tracer signals are found in the NECC current bands near the tracer deployment location. Float $\mathrm{f} 400$ (Fig. 11; light grey) circled in this region starting at the time of deployment and is located at $7.49^{\circ} \mathrm{N}, 19.2^{\circ} \mathrm{W}$ on 9 November 2010, close to a CTD station, with enhanced tracer load transported eastward. South of the NECC (south of $4^{\circ} \mathrm{N}$ ) the tracer signal is almost zero; hence, there ap- 
peared to be no exchange between the NECC and the equatorial region. Tracer spreading around the Guinea Dome and along the float track of float $\mathrm{f} 350$ is visible. Float $\mathrm{f} 350$ was located just northeast of the Cape Verde Islands in November 2010.

The tracer signal between the Cape Verde Islands and Africa along $15^{\circ} \mathrm{N}$ is near zero except for a weak signal at 21 to $22^{\circ} \mathrm{W}$, indicating a weak northward flow component just east of the Cape Verde Islands. Such a northward flow component is consistent with the northward drift of float $\mathrm{f} 350$ and the flow field in October-November 2010. In an earlier description of the subsurface flow in the eastern tropical North Atlantic (Stramma et al., 2008b) it was mentioned that oxygen-poor water east of the Cape Verde Islands is trapped in a cyclonic circulation cell, which agrees with the lowest oxygen concentrations at $350 \mathrm{~m}$ in the climatology (Fig. 6) and the observation that the tracer signal at $15^{\circ} \mathrm{N}$ east of the Cape Verde Islands is very low. Instead of the mean cyclonic circulation reaching from the surface to the OMZ layer as observed in the mean ADCP section at $18^{\circ} \mathrm{N}$ (Brandt et al., 2015), measurements in November 2008 between Cape Verde and the Canary Islands show cyclonic flow in the upper ocean but an anticyclonic circulation cell of $0.8 \mathrm{~Sv}$ for the density layer $\sigma_{\theta}=26.85-27.1 \mathrm{~kg} \mathrm{~m}^{-3}$ in $\sim 300-500 \mathrm{~m}$ depth (Peña-Izquierdo et al., 2012). According to the SODA model, water from the Guinea Dome region is transported northeastward just east of the Cape Verde Islands, which could explain the measurements of weak tracer transport west of the African shelf and possibly slightly enhanced tracer transport east of the Cape Verde Islands.

In November-December 2008, just 7 months after the deployment, the tracer was located closer to the deployment region, and the ship survey was carried out in a smaller region near the deployment site (Fig. S5). The maximum tracer concentration 7 months after the deployment in November 2008 are up to $230 \mathrm{fm} \mathrm{kg}^{-1}$, much larger than the maximum tracer values of $6.5 \mathrm{fm} \mathrm{kg}^{-1}$ in November-December 2009 or $3.9 \mathrm{fm} \mathrm{kg}^{-1}$ in October-November 2010 . The strongest tracer values were observed northeast of the deployment site, with the highest values at about $9^{\circ} \mathrm{N}, 20^{\circ} \mathrm{W}$, and the float f350 also drifted to this region. The two other floats drifted toward the southeast and in this region a westward flow component with enhanced tracer values is present. Some of the tracer drifted around the Guinea Dome and spread westward at $11^{\circ} \mathrm{N}$.

\section{Discussion and conclusion}

In this study the eastern tropical North Atlantic was investigated with a focus on the upper OMZ using SODA model results, ship surveys in November-December 2008, November-December 2009 and October-November 2010, and three floats with oxygen sensors, which were compared to the spreading of a tracer released in April 2008 at $\sim 8^{\circ} \mathrm{N}$, $23^{\circ} \mathrm{W}$. Oxygen sensors of two floats stayed well calibrated for $\sim 20$ months within $1 \mu \mathrm{mol} \mathrm{kg}-1$ for the 100 to $800 \mathrm{~m}$ depth layer in comparison to near CTD-oxygen profiles.

The shipboard oxygen observations in 2008, 2009 and 2010 augmented by four other oxygen cruise measurements are used to determine the deoxygenation trend near the Guinea Dome in the upper OMZ through the year 2014. The linear trend for oxygen since the 1960s in a layer from 100 to $300 \mathrm{~m}$ continues in recent years with a trend of $-0.49 \pm 0.16 \mu \mathrm{mol} \mathrm{kg} \mathrm{gr}^{-1} \mathrm{yr}^{-1}$. For a deeper layer from 300 to $700 \mathrm{~m}$, a weaker, but also continuous, linear trend of $-0.38 \pm$ $0.09 \mu \mathrm{mol} \mathrm{kg}{ }^{-1} \mathrm{yr}^{-1}$ exists despite an oxygen increase in this layer in recent years. This trend is similar to the trend of $-0.34 \pm 0.13 \mu \mathrm{mol} \mathrm{kg}^{-1} \mathrm{yr}^{-1}$ for this layer calculated up to the year 2006 (Stramma et al., 2008a).

Strong eddies as observed in the eastern tropical Pacific off Peru could not be detected in the data set used here south of the Cape Verde Islands. Observations of mesoscale eddies in the eastern tropical Atlantic show less eddy activity than in the eastern tropical Pacific (Chelton et al., 2011). Some indication of eddy activity is seen in the float time series and eddies seem to affect and blur the ADCP flow fields; however, the eddy signal in the ETNA is not as strong and not as deepreaching as in the eastern Pacific off Peru (Stramma et al., 2013). The cyclonic and anticyclonic features in the SSHA field move westward rapidly and the floats stayed in these features for only a few days, different from observations of the eastern tropical South Pacific, where the floats followed the SSHA anomalies for weeks (Czeschel et al., 2015). Eddy activity might be stronger north of the Cape Verde Islands where enhanced eddy activity is visible in satellite data (Chelton et al., 2011), and observations of very low oxygen values were observed in long-lived cyclonic and anticyclonic mode water eddies (Karstensen et al., 2015).

Splitting of the drift components of float tracks at the surface and at subsurface depth shows that the depth of the largest float drift strongly depends on the geographic location. Eastward spreading of the floats in the NECC region south of $9^{\circ} \mathrm{N}$ was governed by a drift at the surface, while at the parking depth at 330 to $400 \mathrm{~m}$ only weak zonal flow influenced the float path. The zonal flow component showed the influence of the seasonal signal of the NECC that, modulated by interannual variations, is related to long Rossby waves (Hormann et al., 2012). The measured eastward surface flow component of the float with a parking depth at $400 \mathrm{~m}$ of $14.4 \mathrm{~cm} \mathrm{~s}^{-1}$ was a little less than the estimated mean NECC core velocity for the region 15 to $40^{\circ} \mathrm{W}$ of $20 \mathrm{~cm} \mathrm{~s}^{-1}$ (Hormann et al., 2012). This velocity difference might be caused by higher NECC velocities in the western Atlantic and the location of the float not propagating in the core of the NECC. In the OMZ region between the Cape Verde Islands and $\sim 9^{\circ} \mathrm{N}$ the northward drift takes place near the parking depth at $350 \mathrm{~m}$. The northwestward drift of the float into the subtropical gyre north of the Cape Verde Islands was due to a combination of westward surface drift and 
subsurface northwestward drift. The measured oxygen and velocity distribution at $350 \mathrm{~m}$ depth slightly above the core of the OMZ shows the signature of a cyclonic flow around about $10^{\circ} \mathrm{N}, 23^{\circ} \mathrm{W}$; hence, the near-surface circulation of the Guinea Dome reaches down to this subsurface layer. The fast northward progression of the float at $350 \mathrm{~m}$ depth in 2009 seems to be connected to a period of strong Guinea Dome caused by an Atlantic Meridional Mode event (e.g., Doi et al., 2010). In addition to the meridional mode event, the combination with a zonal mode event is responsible for a northward drift of the NECC core and a current strengthening (Hormann et al., 2012), which seems to be responsible for the float drift from the NECC region to the Guinea Dome region in boreal summer 2009. Climatology for November-December at $350 \mathrm{~m}$ (Fig. 6) shows the oxygen minimum at about $12.5^{\circ} \mathrm{N}$, $20^{\circ} \mathrm{W}$, northeast of the cyclonic flow of the Guinea Dome region. This oxygen minimum is located in the anticyclonic circulation south of the Cape Verde Islands, indicating weak water renewal in this circulation cell at this depth.

In December 2009 the distribution of the tracer deployed at $\sim 8^{\circ} \mathrm{N}, 23^{\circ} \mathrm{W}$ in April 2008 at the isopycnal $\sigma_{\theta}=26.88 \mathrm{~kg} \mathrm{~m}^{-3}$ shows the integral effect of over 20 months of the flow components of the upper OMZ. The largest tracer signal was observed east of the deployment region, which is in agreement with the nearly barotropic eastward flow between 7.5 and $9.5^{\circ} \mathrm{N}$ found in the mean $23^{\circ} \mathrm{W}$ section by Brandt et al. (2015). Large tracer signals southeast and southwest of the deployment region show the recirculation paths south of the nNECC. Finally large tracer signals north of the deployment region show cyclonic flow around the Guinea Dome. The three floats were deployed together with the tracer in April 2008 at the same location and the spreading paths of the floats are in good agreement with the spreading of the tracer signal.

The different observations as well as the SODA model results show a weak mean flow field (Fig. 12) by averaging the velocity field including seasonal and short-term variability. The eastward flowing NECC is strong in the upper $250 \mathrm{~m}$, while the NEUC below is either weak or flowing westward in agreement with the NECC flow fields derived by PeñaIzquierdo et al. (2015). The nNECC reaches from the surface down to the OMZ layer, and westward flow to the south of the nNECC at subsurface layers is clearly visible in zonal velocity sections in November 2009 (Fig. 5) and in the mean $23^{\circ} \mathrm{W}$ velocity sections (Brandt et al., 2010). The velocity section at $23^{\circ} \mathrm{W}$ north of $10^{\circ} \mathrm{N}$ as well as velocity sections reported in the literature confirm that the near-surface flow often reaches down to the low oxygen layer. The nearsurface cyclonic circulation cell east of the Cape Verde Islands described by Mittelstaedt (1983) reaches down into the OMZ layer. The eastward flow south of the Cape Verde Islands, named the Cape Verde Current by Peña-Izquierdo et al. (2015), seems to be a permanent eastward recirculation of the westward flow component of the Guinea Dome. The higher NACW contribution compared to SACW in the lower

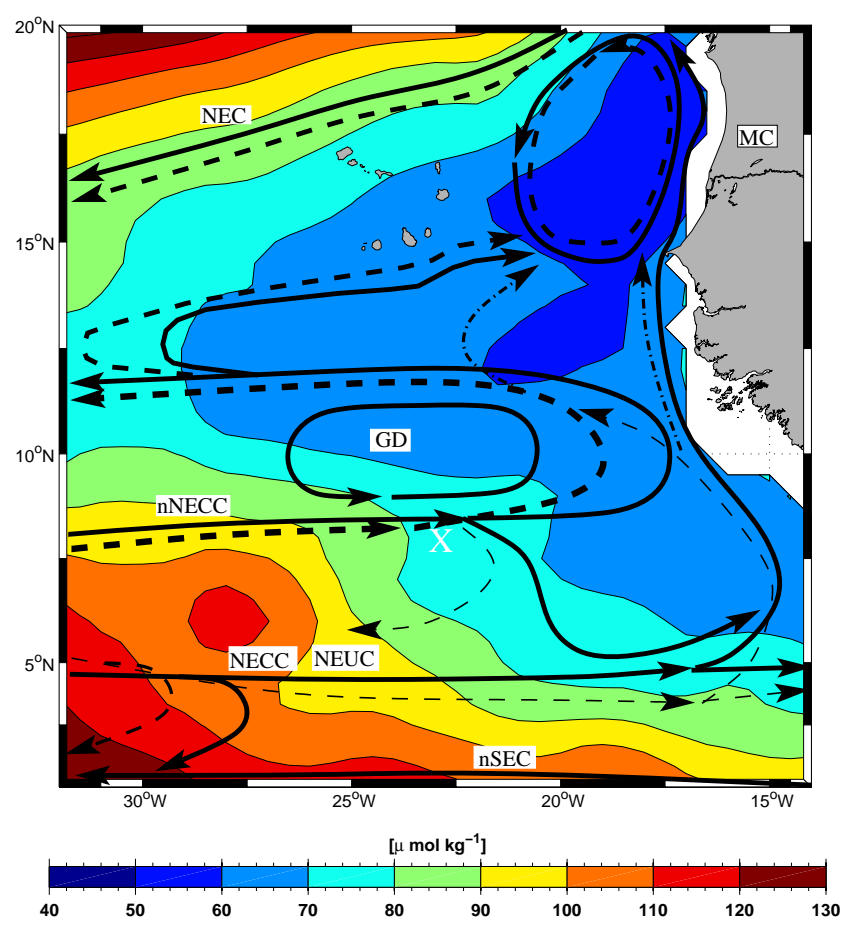

Figure 12. Schematic flow field based on the results from this investigation and on earlier schematics (e.g., Mittelstaedt, 1983; Stramma and Schott, 1999; Stramma et al., 2008b; Peña-Izquierdo et al., 2012; Brandt et al., 2015) shown as solid black lines for the upper ocean to about $200 \mathrm{~m}$ depth and as dashed black lines for the layer 200 to $400 \mathrm{~m}$. The two dash-dotted lines indicate possible different paths of the 200 to $400 \mathrm{~m}$ layer; thin lines indicate weak or reversing currents. For current names please refer to the text. The white cross at $\sim 8^{\circ} \mathrm{N}, 23^{\circ} \mathrm{W}$ marks the location of the tracer release. Annual mean climatological oxygen distribution (color) at 350 m depth from CARS 2009 climatology (Ridgway et al., 2002).

Central Water layers south of the Cape Verde Islands (e.g., Tomczak, 1984; Peña-Izquierdo et al., 2015) appears to be related to the weak SACW inflow in the weak NEUC flow at about $5^{\circ} \mathrm{N}$ compared to strong SACW inflow in the NECC above in the upper Central Water and the enhanced contribution of NACW nNECC (Lumpkin and Garzoli, 2005).

In vector plots of snapshots of the horizontal flow field combined with oxygen and tracer measurements (Figs. 6, 10 and 11), the mean large-scale circulation signal is obscured by the meridional variability in the current bands as observed in the ship surveys and in the SODA velocity field. It is further overlain by circulation changes caused by climate modes such as the AMM and mesoscale variability. Despite large variability in snapshots of the ADCP-derived flow field, the different measurements used and combined here demonstrate that circulation of the upper OMZ widely mirrors the near-surface circulation (Fig. 12). Exceptional cases are the weak 200 to $400 \mathrm{~m}$ flow below the NECC and an enhanced westward excursion of the 200 to $400 \mathrm{~m}$ flow north of the Guinea Dome at about $12^{\circ} \mathrm{N}$. Based on additional data sets 
a more detailed description of the OMZ flow field than that presented by Stramma et al. (2008b) could be derived here. While the floats and tracer spreading results enabled a better understanding of the circulation on a density or depth surface, the mean three-dimensional flow field can only be derived by averaging repeated hydrographic sections and thus removing the variability present in snapshots of the flow field from single ship surveys.

\section{The Supplement related to this article is available online at doi:10.5194/os-12-153-2016-supplement.}

Acknowledgements. The Deutsche Forschungsgemeinschaft (DFG) provided support as part of the Sonderforschungsbereich 754: Climate-Biogeochemistry Interactions in the Tropical Ocean and the Deutsche Bundesministerium für Bildung und Forschung (BMBF) as part of AWA (01DG12073E). The altimeter data were produced by Ssalto/Duacs and distributed by Aviso with support from Centre natinal d'etudes spatiales. The Argo float profiles are available from ftp://ftp.ifremer.fr/ifremer/argo/dac/coriolis. Partial funding for BSG was provided by NSF from award ACI 1049075.

Edited by: M. Hecht

\section{References}

Banyte, D., Tanhua, T., Visbeck, M., Wallace, D. W. R., Karstensen, J., Krahmann, G., Schneider, A., Stramma, L., and Dengler, M.: Diapycnal diffusivity at the upper boundary of the tropical North Atlantic oxygen minimum zone, J. Geophys. Res., 117, C09016, doi:10.1029/2011JC007762, 2012.

Banyte, D., Visbeck, M., Tanhua, T., Fischer, T., Krahmann, G., and Karstensen, J.: Lateral diffusivities from tracer release experiments in the tropical North Atlantic thermocline, J. Geophys. Res., 118, 1-15, 2013.

Boyer, T. P., Antonov, J. I., Baranova, O. K., Garcia, H. E., Johnson, D. R., Locarnini, R. A., Mishonov, A. V. Seidov. D., Amolyar, I. V., and Zweng, M. M.: World Ocean Database 2009 [DVDs], Noaa Atlas Nesdis, vol. 66, edited by: S. Levitus, US Govt. Print. Off., Washington, DC USA, 216 pp., 2009.

Brandt, P., Hormann, V., Körtzinger, A., Visbeck, M., Krahmann, G., Stramma, L., Lumpkin, R., and Schmid, C.: Changes in the ventilation of the oxygen minimum zone of the tropical North Atlantic, J. Phys. Oceanogr., 40, 1784-1801, doi:10.1175/2010JPO4301.1, 2010.

Brandt, P., Bange, H. W., Banyte, D., Dengler, M., Didwischus, S.-H., Fischer, T., Greatbatch, R. J., Hahn, J., Kanzow, T., Karstensen, J., Körtzinger, A., Krahmann, G., Schmidtko, S., Stramma, L., Tanhua, T., and Visbeck, M.: On the role of circulation and mixing in the ventilation of oxygen minimum zones with a focus on the eastern tropical North Atlantic, Biogeosciences, 12, 489-512, doi:10.5194/bg-12-489-2015, 2015.

Carton, J. A. and Giese, B. S.: A reanalysis of ocean climate using SODA, Mon. Weather Rev., 136, 2999-3017, 2008.
Carton, J. A., Cherupin, G., Cao, X., and Giese, B. S.: A simple ocean data assimilation analysis of the global upper ocean 1950-1995, Part I: Methodology, J. Phys. Oceanogr., 30, 294309, 2000.

Chelton, D. B., Schlax, M. G., and Samelson, R. M.: Global observations of nonlinear mesoscale eddies, Prog. Oceanogr., 91, 167-216, 2011.

Chu, P. C., Ivanov, L. M., Melnichenko, O. V., and Wells, N. C.: On long baroclinic Rossby waves in the tropical North Atlantic observed from profiling floats, J. Geophys. Res., 112, C05032, doi:10.1029/2006JC003698, 2007.

Compo, G. P., Whitaker, J. S., Sardeshmukh, P. D., Matsui, N., Allan, R. J., Yin, X., Gleason, B. E., Vose, R. S., Rutledge, G., Bessemoulin, P., Brönnimann, S., Brunet, M., Crouthamel, R. I., Grant, A. N., Groisman, P. Y., Jones, P. D., Kruk, M. C., Kruger, A. C., Marshall, G. J., Maugeri, M., Mok, H. Y. Nordli, Ø., Ross, T. F., Trigo, R. M., Wang, X. L.,Woodruff, S. D., and Worley, S. J.: The Twentieth Century Reanalysis Project, Q. J. R. Meteorol. Soc., 137, 1-28, 2011.

Cravatte, S., Kessler, W. S., and Marin, F.: Intermediate zonal jets in the tropical Pacific Ocean observed by Argo floats, J. Phys. Oceanogr., 42, 1475-1485, 2012.

Czeschel, R., Stramma, L., Weller, R. A., and Fischer, T.: Circulation, eddies, oxygen and nutrient changes in the eastern tropical South Pacific, Ocean Sci., 11, 455-470, doi:10.5194/os-11-455, 2015.

Deans, S. R.: The Radon Transform and Some of its Applications, John Wiley, Hoboken, NJ, USA, 1983.

Doi, T., Tozuka, T., and Yamagata, T.: The Atlantic Meridional Mode and its coupled variability with the Guinea Dome, J. Climate, 23, 455-475, 2010.

Duteil, O., Schwarzkopf, F. U., Böning, C. W., and Oschlies. A.: Major role of the equatorial current system in setting oxygen levels in the eastern tropical Atlantic Ocean: A highresolution model study, Geophys. Res. Lett., 41, 2033-2040, doi:10.1002/2013GL058888, 2014.

Fischer, T., Banyte, D., Brandt, P., Dengler, M., Krahmann, G., Tanhua, T., and Visbeck, M.: Diapycnal oxygen supply to the tropical North Atlantic oxygen minimum zone, Biogeosciences, 10, 5079-5093, doi:10.5194/bg-10-5079-2013, 2013.

Foltz, G. R., McPhaden, M. J., and Lumpkin, R.: A strong Atlantic Meridional Mode event in 2009: The role of mixed layer dynamics, J. Clim., 25, 363-380, 2012.

Giese, B. S. and Ray, S.: El Niño variability in simple ocean data assimilation (SODA), 1871-2008, J. Geophys. Res., 116, C02024, doi:10.1029/2010JC006695, 2011.

Giese, B. S., Chepurin, G. A., Carton, J. A., Boyer, T. P., and Seidel, H. F.: Impact of bathythermograph temperature bias models on an ocean reanalysis, J. Clim, 24, 84-93, 2011.

Gnanadesikan, A., Bianchi, D., and Pradal, M.-A.: Critical role for mesoscale eddy diffusion in supplying oxygen to hypoxic ocean waters, Geophys. Res. Lett., 40, 5194-5198, 2013.

Hahn, J., Brandt, P., Greatbatch, R. J., Krahmann, G., and Körtzinger, A.: Oxygen variance and meridional oxygen supply in the tropical North East Atlantic oxygen minimum zone, Clim. Dynam., 43, 2999-3024, 2014.

Hansen, H. P.: Determination of oxygen. In: Methods of Seawater analysis, edited by: Grasshoff, K. K. and Ehrhardt, M., WileyVCH, Weinheim, Germany, 75-89, 1999. 
Ho, D. T., Ledwell, J. R., and Smethie Jr., W. M.: Use of $\mathrm{SF}_{5} \mathrm{CF}_{3}$ for ocean tracer release experiments, Geophys. Res. Lett., 35, L04602, doi:10.1029/2007GL032799, 2008.

Hormann, V., Lumpkin, R., and Foltz, G. R.: Interannual North Equatorial Countercurrent variability and its relation to tropical Atlantic climate modes, J. Geophys. Res., 117, C04035, doi:10.1029/2011JC007697, 2012.

Kalvelage, T., Lavik, G., Lam, P., Contreras, S., Arteaga, L., Löscher, C. R., Oschlies, A., Paulmier, A., Stramma, L., and Kuypers, M. M. M.: Nitrogen cycling driven by organic matter export in the South Pacific oxygen minimum zone, Nature Geosci., 6, 228-234, 2013.

Karstensen, J., Stramma, L., and Visbeck, M.: Oxygen minimum zones in the eastern tropical Atlantic and Pacific oceans, Prog. Oceanogr., 77, 331-350, 2008.

Karstensen, J., Fiedler, B., Schütte, F., Brandt, P., Körtzinger, A., Fischer, G., Zantopp, R., Hahn, J., Visbeck, M., and Wallace, D.: Open ocean dead zones in the tropical North Atlantic Ocean, Biogeosciences, 12, 2597-2605, doi:10.5194/bg-12-2597-2015, 2015

Levitus, S., Antonov, J. I., Boyer, T. P., Locarnini, R. A., Garcia, H. E., and Mishonov, A. V.: Global ocean heat content 1955-2007 in light of recently revealed instrumentation problems, Geophys. Res. Lett., 36, L07608, doi:10.1029/2008GL037155, 2009.

Lumpkin, R. and Garzoli, S. L.: Near-surface circulation in the tropical Atlantic Ocean, Deep-Sea Res. Pt. I, 52, 495-518, 2005.

Machin, F. and Pelegrí J. L.: Northward penetration of Antarctic Intermediate Water off Northwest Africa, J. Phys. Oceanogr., 39, 512-535, 2009.

McGillicuddy Jr., D. J., Anderson, L. A., Bates, N. R., Bibby, T., Buesseler, K. O., Carlson, C. A., Davis, C. S., Ewart, C., Falkowski, P. G., Goldthwait, S. A., Hansell, D. A., Jenkins, W. J., Johnson, R., Kosnyrev, V. K., Ledwell, J. R., Li, Q. P., Siegel, D. A., and Steinberg, D. K.: Eddy/wind interactions stimulate extraordinary mid-ocean plankton blooms, Science, 316, 10211026, 2007.

Mittelstaedt, E.: The upwelling area off Northwest Africa - a description of phenomena related to coastal upwelling, Prog. Oceanogr., 12, 307-331, 1983.

Peña-Izquierdo, J., Pelegrí, J. L., Pastor. M. V., Castellanos, P., Emilianov, M., Gasser, M., Salvador, J., and VasquezDominguez, E.: The continental slope current system between Cape Verde and the Canary Islands, Sci. Mar., 76, 65-78, 2012.

Peña-Izquierdo, J., van Sebille, E., Pelegrí, J. L., Sprintall, J., Mason, E., Llanillo, P. J., and Machín, F.: Water mass pathways to the North Atlantic oxygen minimum zone, J. Geophys. Res. Oceans, 120, 3350-3372, 2015.

Richardson, P. L. and Reverdin, G.: Seasonal cycle of velocity in the Atlantic North Equatorial Countercurrent as measured by surface drifters, current meters, and ship drift, J. Geophys. Res., 92, 3691-3708, 1987.
Ridgway, K. R., Dunn, J. R., and Wilkin, J. L.: Ocean interpolation by four-dimensional least squares-Application to the waters around Australia, J. Atmos. Oceanol. Technol., 19, 1357-1375, 2002.

Rosell-Fieschi, M., Pelegrí, J. L., and Gourrion, J.: Zonal jets in the equatorial Atlantic Ocean, Prog. Oceanogr., 130, 1-18, 2015.

Schott, F., Fischer, J., and Stramma, L.: Transports and pathways of upper-layer circulation in the western tropical Atlantic, J. Phys. Oceanogr., 28, 1904-1928, 1998.

Siedler, G., Zangenberg, N., Onken, R., and Morliere, A.: Seasonal changes in the tropical Atlantic circulation: Observations and simulations of the Guinea Dome, J. Geophys. Res., 97, 703-715, 1992.

Stramma, L. and Schott, F.: The mean flow field of the tropical Atlantic Ocean, Deep-Sea Res. Pt. II, 46, 279-303, 1999.

Stramma, L., Hüttl, S., and Schafstall, J.: Water masses and currents in the upper tropical northeast Atlantic off northwest Africa, J. Geophys. Res., 110, C12006, doi:10.1029/2005JC002939, 2005.

Stramma, L., Johnson, G. C., Sprintall, J., and Mohrholz, V.: Expanding oxygen-minimum zones in the tropical oceans, Science, 320, 655-658, 2008a.

Stramma, L., Brandt, P., Schafstall, J., Schott, F., Fischer, J., and Körtzinger, A.: Oxygen minimum zone in the North Atlantic south and east of the Cape Verde Islands, J. Geophys. Res., 113, C04014, doi:10.1029/2007JC004369, 2008b.

Stramma, L., Visbeck, M., Brandt, P., Tanhua, T., and Wallace, D.: Deoxygenation in the oxygen minimum zone of the eastern tropical North Atlantic, Geophys. Res. Lett., 36, L20607, doi:10.1029/2009GL039593, 2009.

Stramma, L., Prince, E. D., Schmidtko, S., Luo, J., Hoolihan, J. P. Visbeck, M., Wallace, D. W., Brandt, P., and Körtzinger, A.: Expansion of oxygen minimum zones may reduce available habitat for tropical pelagic fishes, Nat. Clim. Change, 2, 33-37, doi:10.1038/NCLIMATE1304, 2012.

Stramma, L., Bange, H. W., Czeschel, R., Lorenzo, A., and Frank M.: On the role of mesoscale eddies for the biological productivity and biogeochemistry in the eastern tropical Pacific off Peru, Biogeosciences, 10, 7293-7306, doi:10.5194/bg-10-7293-2013, 2013.

Tomczak, M.: Ausbreitung und Vermischung der Zentralwassermassen in den Tropengebieten der Ozeane. 1: Atlantischer Ozean, Oceanol. Acta, 7, 145-158, 1984.

Urbano, D. F., Jochum, M., and da Silveira, I. C. A.: Rediscovering the second core of the Atlantic NECC, Ocean Model., 12, 1-15, 2006.

Urbano, D. F., De Almeida, R. A. F., and Nobre, P.: Equatorial Undercurrent and North Equatorial Countercurrent at $38^{\circ} \mathrm{W}$ : A new perspective from direct velocity data, J. Geophys. Res, 113, C04041, doi:10.1029/2007JC004215, 2008.

Winkler, L. W.: Bestimmung des im Wasser gelösten Sauerstoffs, Ber. Dtsch. Chem. Ges., 21, 2843-2855, 1888. 